\title{
Mustafa El-Galâyînî'nin Şiir Anlayışı ve Siyasi Şiirleri
}

\author{
Mustafa Al-Ġalāyīnī's Poetry and Political Poems
}

\section{Ali Benli* ${ }^{*}$}

Öz

Bu çalışmada daha çok Arapça dilbilgisi alanındaki çalışmalarıyla tanınan Lübnanlı edip ve âlimlerden Mustafa elGalâyînî’nin şairliği, şiirle ilgili görüşleri ve şiirlerindeki siyasi temalar, özellikle de Osmanlı Devleti ve Türkiye tarihi ile ilgili olanlar üzerinde durulmuştur. Bu çerçevede öncelikle Galâyînî’nin kısa bir biyografisi verilmiş, eserleri tanıtılmıştır. Daha sonra Divan'ına yazdığı giriş yazısı çerçevesinde şiir ile ilgili görüşleri özetlenmiştir. Galâyînî yazdığı makaleler, çeşitli mahfillerde yaptı̆̆ konuşmalar, yayın hayat iki yıl süren en-Nibrâs adlı dergisinde yayımladığı yazılarla sosyal ve siyasi hayatın içinde faal bir şekilde yer almış bir şahsiyettir. İttihâd ve Terakkî’nin faaliyetlerine katılmış, I. Dünya Savaşı sırasında Osmanlı Ordusu'nda hatip olarak görev almış, Süveyş harekâtına iştirak etmiş, daha sonra Arap devletinin kuruluşunda katkılarda bulunmuş, Lübnan'daki Fransız idaresine karşı tutumu sebebiyle bir süre hapiste yatmıştır. Siyasî ve sosyal çalkantılarla dolu bir dönemde yaşayan Galâyînî, şiiri toplumu ıslah etmek, ona yol göstermek için kullanılacak bir araç olarak görmüş ve şahit olduğu olaylar ve toplumun ıslahı konusunu şiirlerinde yoğun bir şekilde işlemiştir. Bu makalede Galâyînî’nin Osmanlı Devleti, II. Meşrutiyet'in ilanı, Sultan Abdülhamid'in tahttan indirilmesi, Birinci Dünya Savaşı ve etkileri, Türk-Arap kardeşliği, Türk istiklal mücadelesi ve Arap milliyetçiliği gibi konuları şiirlerinde nasıl işlediği incelenmiş ve dönem edebiyatçılarının bu konulara bakışları arasında sahip olduğu yer tespit edilmeye çalışılmıştır.

\section{Anahtar Kelimeler}

Mustafa el-Galâyînî, II. Meşrutiyet, Arap Milliyetçiliği, II. Abdülhamid, Mustafa Kemal

\begin{abstract}
This article examines the works of Mustafa el-Galāyānī a well-known Lebanese scholar and writer. It specifically looks at his views on poetry, politics and the history of Ottoman State and Turkey. First, it presents a short summary of Galāyānī's life and works, and his view on poetry based on his introduction to the Divan. Galāyānī's articles, speeches and writings in the journal of en-Nibrās show that he was actively involved in the social and political life of the time. He participated in the activities of the Committee of Union and Progress, joined the Ottoman Army as a preacher, involved in the Suez Campaign, and then contributed to the foundation of Arab state. Due to his resistance against the French rule he was put into prison. Galāyīnī lived in a turbulent period and used his poetry as a means to improve society. He often made use of his own personal experiences in his poems. This article discusses Galāyīnī's views on various issues such as the Ottoman State, the introduction of II. Constitution, the fall of Sultan Abdulhamid, World War I, Turkish-Arab brotherhood, Turkish War of Indpendence, Arab nationalism, and understand his position among the other men of literature of the time.
\end{abstract}

\section{Keywords}

Mustafa al-Galāyīnī, II. Constitution, Arab nationalism, Abdülhamid II, Mustafa Kemal

\footnotetext{
* Sorumlu Yazar: Ali Benli (Dr. Öğr. Üyesi), Marmara Üniversitesi İlahiyat Fakültesi, Arap Dili ve Belagatı Anabilim Dalı, İstanbul, Türkiye. E-posta: ali.benli@marmara.edu.tr ORCID: 0000-0003-3257-8969
}

Atıf: Ali Benli, “Mustafa El-Galâyînî’nin Şiir Anlayışı ve Siyasi Şiirleri.” darulfunun ilahiyat 32, 1 (2021): 1-34. https://doi.org/10.26650/di.2021.32.1.866190 


\section{Extended Summary}

Muștafā al-Ġalāyīn̄i is an influential Arabic literary critic who published many works on the Arabic language in the first half of the 20th century. This article consists of alĠalāyīn̄̄'s biography, a brief introduction to his works, his views on poetry, and concludes with a discussion of al-Ġalāyīn̄̄'s own political poems.

Al-Ġalāyīn̄̄ was born in Beirut in 1886 where he began receiving his first education. Upon completing his studies there, he went to Cairo to study in al-Azhar University in 1903. Here, he attended and was influenced by Muhammed Abduh and Sayyid Mersafî's lectures. He began his publishing career in Egypt with numerous articles he had written for a variety of newspapers and journals during his pupilage. After completing his education al-Azhar, al-Ġalāyīn̄̄ returned to Beirut and was appointed as a teacher. He published an-Nibrās journal in 1909 which continued to be published for two years. He joined the Committee of Union and Progress and supported the Ottoman caliphate whilst aiming to find a common ground between the Turks and the Arabs during the time. He served as a military chaplain for the 4th army of the Ottoman Empire during the First World War. With the result of a failed military campaign he left for Damascus to join Prince Faisal's campaign and served there as the head of the bureau of correspondence (diwān al-rasā' 'il). After the French invasion of Damascus in 1920 al-Ġalāyīnī went to Amman; however, after he went back to Beirut he got under arrest by the French administration and was imprisoned for seven months. Al-Ġalāyīn̄ once again returned to Beirut in 1925 and spent the rest of his life working for various government offices. He died in Beirut in 1944.

Mustafa al-Ġalāyīn̄ has been a scholar who was actively involved in the social community he was a part of with the many teaching books he had written, in addition to numerous newspaper articles, as well as the many lectures he gave in different places and occasions throughout the course of his life. He did not shy away in getting involved in controversial debates of his time, replying to Lord Cromer's criticisms of Islam in his book Modern Egypt as well as claims made by Nazīre Zayn al-Dīn in al-Sufūr wa al-hijāab regarding women rights in Islam. Al-Ġalāyīnī has been influential on the young generation with his long teaching experience and has endeavored to broaden their perspectives as well as to generate and develop their nationalist sentiments. He continued to remain influential with his articles, poems, and opinions from his teaching years at alAzhar until his death in 1944.

Although al-Ġalāyīn̄i is more famous for his works in the Arabic grammar, he is also mentioned among the famous poets and literary critics of his time. Similar to his contemporaries, he also mentions current social and political activities of the time in his poems. Having led educational enterprises, publishing and editorial works, as well as with his political activism al-Ġalāyīn̄ has been subject to many debates during his lifetime. 
Al-Ġalāyīnī is renowned to have advocated the practice of a poetic tradition against the struggles and turmoil of the time, having composed poems about the restoration of the constitutional monarchy, First World War, the Arab Revolt, and the French invasion of Lebanon and the subsequent independence war. Al-Ġalāȳin̄ supported the Ottoman solidarity, the revival of the Arabic language and culture, youth education, as well as to facilitate women participation in social life.

Al-Ġalāyīnī supported the Committee of Union and Progress's policies and has had similar to ottomanist views. He celebrated the restoration of the constitutional monarchy and Abdul Hamid II's deposition in his poems. He served in the Ottoman army during the First World War and called out to all Muslims to persevere in unity and not fall into dispute until the Ottomans were forced to retreat from the Middle East. In a later period, he has been an ally of Sharif Hussein and endeavored to develop Arab nationalist sentiments and to unite all Arabs under this cause. He has played an active role in the conflict against the allied forces in the period following the First World War and has been imprisoned by the French administration as a result. His poem in which he advised the Arabs in their conflicts against the colonial powers to take the example of Mustafa Kemal Atatürk in his leading role during the War of Independence is worthy of notice. 


\section{Giriş}

On dokuzuncu yüzyıl ile yirminci yüzyılın ilk yılları büyük siyasî, fikrî ve içtimaî kırılmaların ve dönüşümlerin yaşandığı bir dönemdir. Söz konusu olayların etkisi Arap edebiyatında da görülmüş ve yeni temaları, duyuş ve düşünüş tarzları ve türleriyle Yeni/Modern Arap Edebiyatı devresi başlamıştır. Batı'da gelişen edebî akımlar Arap edebiyatında çeşitli yönleriyle yankı ve temsilciler bulmuştur. Sosyal ve siyasi problemler ve bunlarla ilgili düşünceler şiir ve edebiyatta daha fazla ve doğrudan yankı bulur hale gelmiştir. Bu dönemde Lübnan'da Emîn Nâsıruddîn (18751953), Fuâd el-Hatîb (1880-1957), İlyâs Ferhât (1893-1977); Suriye' de Fâris el-Hûrî (1873-1962), Muhammed el-Bezm (1887-1955), Cemil Merdüm Bey (1890-1951), Bedreddîn Hâmid (1901-1961); Irak'ta Ma 'rûf er-Rusâfî (1875-1945), Muhammed Rıza eş-Şebîbî (1889-1965), Cemîl Sidkî ez-Zehâvî (1863-1936); Mısır’da Ahmed Şevkî (1868-1932), Hâfiz İbrahim (1873-1932), Ahmed Muharrem (1877-1945) gibi şairler siyâsî ve sosyal hadiseleri şiirlerinde işlemişlerdir. ${ }^{1}$ Toplumdaki gelişmelere paralel olarak Doğu ve Batı medeniyetlerinin karşılaştırılması, vatan sevgisi, hürriyet, adalet, kadının toplumdaki konumu, eğitim öğretim meselesi, eski geleneklerin eleştirisi, halka özellikle de gençlere yeni bir mücadele gücü aşılanması gibi konular şiirlerde yer bulmaya başlamıştır. Bu dönemde Arapların eski çağlarındaki yüksek başarılarının toplumun zihninde yeniden canlandırılması için tarihî temalar da edebiyat ürünlerinde daha çok işlenmiştir.

Yeni Arap edebiyatının başlangıç döneminde şairlerin büyük kısmı, şekil olarak klasik Arap edebiyatının kalıplarını ihya etmeye çalışmışlardır. Bu dönemin öncü şairlerinden Mahmud Sâmî el-Barûdî, Ahmed Şevkî ve Hâfiz İbrahim eski şiirin imkânlarından faydalanmışlardır. Onların geleneksel şiire getirdikleri yenilik şekilden çok ele aldıkları konular ve genel yaklaşımlarıyla ilgilidir ve asıl amaçları klasik şiire kaybettiği canlılığı yeniden kazandırmaktır. ${ }^{2}$ Daha çok dil ilimlerine dair kitaplarıyla tanınan Mustafa el-Galâyînî de bu dönemin genel anlayışını temsil eden edebiyatçı ve şairler arasında sayılabilir.

Mustafa el-Galâyînî döneminin diğer edip ve şairleri gibi sosyal ve siyasi konulara şiirlerinde geniş yer vermiştir. Galâyînî, yürüttüğü eğitim, basım ve yayın faaliyetleri ve ıslahçı kimliği ile dönemin tartışmalarında kendisine yer bulmuş bir isimdir. Yaşadığı karmaşık ve çalkantılı dönemde şiirin toplumun ıslahı için kullanılması gerektiğini dile getiren şair, meşrutiyetin ilanı, Birinci Dünya Savaşı, Arap isyanı, Lübnan'ın Fransızlar tarafından işgali ve bağımsızlık mücadelesi gibi olaylar hakkında şiirler yazmıştır. Osmanlı-İslam vurgusu, Arap dilinin ve kültürünün

1 Vilyem el-Hâzin, "Melâmihu'l-kavmiyye fi'ş-şi'ri'l-'arabiyyi'l-hadîs”, el-Edîb 2 (1978), 15-16.

2 Abdullah Hıdır Hamed, Kadâyâ'ş-şi 'ri'l- 'Arabiyyi'l-hadîs, (Beyrut: Dâru'l-Kalem, t.y.), 27-28. 
ihyası, gençlerin eğitimi, kadınların sosyal hayatta yer almasının sağlanması gibi konular da gündeminde olmuştur. ${ }^{3}$

\section{Mustafa el-Galâyînî’nin Hayatı}

Mustafa b. Muhammed Selîm b. Muhyiddin b. Mustafa el-Galâyînî, 1886 yılında Beyrut'ta doğdu. Ailesi Ürdün'ün Akabe şehri ile Hicaz bölgesi arasında yerleşmiş bulunan Huveytât kabilesinin Fevâid aşiretine mensuptur. ${ }^{4}$ Beyrut'ta yetişti ve ilk tahsilini orada yaptı. Mekteb-i İbtidâî'de Şeyh Receb Cemaleddin (18481910) ve Şeyh Muhyiddin el-Hayyât'tan (1875-1914) ders aldı. Dil ilimlerinde derinleşmesinde bu iki hocasından çokça istifade ettiğini belirtir. ${ }^{5}$ Mektep tahsilinin yanında Beyrut'taki cami derslerini de takip etti ve Beyrut Müftüsü Şeyh Abdulbâsıt el-Fâhûrî (1824-1905), Şeyh Sâlih er-Râfiî (ö. 1848-1910) ve Şeyh Abdurrahman el-Hût (1846-1916) gibi hocalardan okudu. 1903 sonlarında Misır'a gidip Ezher'e kaydolarak öğrenimine orada devam etti. Mısır'daki hocaları arasında Muhammed Abduh (1849-1905), Seyyid Mersafî (ö. 1931), ve Şeyh Abdurrahman eş-Şirbînî (ö. 1908) bulunur. ${ }^{6}$ Bir makalesinde Ezher'deki öğrenciliği döneminde çeşitli dergilerde makaleler yayınladığına işaret etmiştir. ${ }^{7}$

Ezher'de öğrenimini tamamladıktan sonra Beyrut'a döndü ve el-Câmi'u'l-Ömerî ve el-Kulliyyetu'ş-Şer'iyye'de öğretmenlik yaptı. ${ }^{8} 1910$ yılında Beyrut Mekteb-i Sultânî'sinde Arapça ve dinî ilimler hocalığ yapmaya başladı. el-Mufíd ve Lisânu'lIttihâd gibi gazetelerde yazıları yayımland1. 1909'da yayın hayatı iki yıl süren enNibrâs dergisini kurdu. İttihad ve Terakkî Partisi’ne katıldı. Bu dönemde Türklerle Arapların arasını bulmak isteyen, halifeyi destekleyen bir siyaset takip etti. ${ }^{9}$ Bir süre sonra bu partiden ayrılıp Hürriyet ve İtilaf Partisi'ne ardından Islah Partisi'ne katıldı. ${ }^{10}$

3 Süheyle Rîmâvî - Bâsim ed-Dehâmişe, "eş-Şeyh Mustafa el-Galâyînî: Hayâtuhu ve fikruh 1886-1945)", Dirâsât: el- 'ulûmu'l-insâniyye ve'l-ictimâ 'iyye 26 (ek) (1999): 830.

4 Mustafa el-Galâyînî, Dîvânu'l-Galâyînî, (Hayfa: el-Matbaatu'l-Abbâsiyye, 1925), 37. Galâyînî'nin Divân' 'nda iki sayfalık bir otobiyografisi bulunmaktadır. Ayrıca yazar eserinde tutuklu bulunduğu dönemde yazdığı şiirleri topladığı bölümün girişine tutuklanması ve tutuklu bulunduğu yıllar ile ilgili ayrıntılı açıklamalar yapmıştır.

5 Galâyînî, Dîvân, 37.

6 Galâyînî, Dîvân, 37.

7 Galâyînî, el-İslâm rûhu'l-medeniyye, (Beyrut: 1907), 35-36.

8 Hayruddin ez-Ziriklî, el-A 'lâm, (Beyrut: Dâru'l-İlm li'l-Melâyîn, 2002) 7/244-245; Yusuf Mar'aşlî, Nesrü'l-cevâhir ve'd-durer fî 'ulemâi'l-karni'r-râbi' 'aşer, (Beyrut: Dâru'l-Ma'rife, 2006) 2:1608; Yılmaz Özdemir, 19. Yüzyılda Lübnan'da Arap Dili Grameri Çalışmaları, Marmara Üniversitesi Sosyal Bilimler Enstitüsü, Doktora Tezi, İstanbul 2005, 286.

9 Mar'aşlî, Nesrü'l-Cevahir, 2/1608; Mahmud Saîd eş-Şâfîi Teşnîfü'l-esmâ' bi-şuyûhi'l-icâze ve's-semâ', (Kahire: Dâru'l-Kutubi'l-Mısriyye, 2013) 2/691-693; Tâhâ el-Velî, Beyrût fi 't-târîh ve'l-hadâra ve'l- 'umrân, (Beyrut: Dâru'l-İlm li'l-Melâyîn, 1993), 314.

10 Süheyle er-Rîmâvî vd. "eş-Şeyh Mustafa el-Galâyînî”, 830. 
Birinci Dünya Savaşı sırasında Osmanlı ordusuna katıldı ve bir süre Dimaşk'ta ikamet etti ve gazetelerde yayınlar yapt1. ${ }^{11}$ Dördüncü Ordu Hatibi olarak Süveyş Harekâtı'nda bulundu. Harekâtın başarısızlığa uğramasından sonra Kral Faysal döneminde Şam'a gitti. el-'Arabiyyetu'l-Fetât Cemiyeti'ne üye oldu. Kral Faysal'ın yanında Dîvân-1 Resâil müdürlüğü yaptı. ${ }^{12}$

23 Temmuz 1920'deki Meyselun Savaşı'ndan sonra Dimaşk, Fransızların eline düşünce bir süre polis merkezinde tutuklu kaldı. Ardından serbest bırakıldı ve kendisine Dimaşk' 1 terk edip Beyrut'a gitmesi söylendi. Beyrut'ta birkaç ay kaldıktan sonra Emir Abdullah'ın Amman'a geçtiğini öğrenince Nisan 1921'de Beyrut'tan Amman'a intikal etti. Orada Dımaşk'ta olduğu gibi Dîvân-1 Resâil başkanlığına getirildi. Galâyînî 1922'de ailesini getirmek üzere Beyrut'a döndü. Bu sırada Beyrut'ta Dâhiliye müdürü Esad Hurşid'e suikast düzenlendi, pek çok Beyrutlu ve Şamlı olayın ardından tutuklandı. Beyrut'ta tutuklananlar arasında yazar da bulunmaktayd $1 .{ }^{13}$ İki ay Beyrut’taki polis merkezinde beş ay Ervad adasındaki kalede toplam yedi ay tutuklu kaldı. Bu müddet boyunca kendisi hiçbir soruşturma geçirmemiştir. Ervad Hapishanesi’nde kendisiyle birlikte kalanlar arasında Suriyeli siyasetçi ve yazar Abdurrahman Şehbender de bulunmaktadır. ${ }^{14}$ Yedi aylık hapisten sonra Hayfa'ya sürgün edildi. ${ }^{15}$ Burada bulunduğu süre zarfında Hayfa'da yayınlanan ez-Zehra dergisinde bazı şiirlerini ve makalelerini yayımlad $1 .{ }^{16}$

11 ez-Zehra dergisinde yayınlanan bir "Serikatü Kındîl" adlı bir şiirinin baş tarafında verilen kısa bilgi notunda şairin 1914-1915 yıllarında Dimaşk'ta ikamet ettiği ve bu şiirini ilk kez orada yazıp er-Ra 'yu'l- 'ām gazetesinde neşrettiği kaydedilmiştir. (Galâyînî, "Serikatu Kındîl (Kasîde)", ez-Zehra, Eylül 1925, y1l 5, sayı: 3, s. 137-138.)

12 Süheyle er-Rîmâvî vd. "eş-Şeyh Mustafa el-Galâyîn̂̂”, 830; Zeki Muhammed Mücâhid, elA 'âmu'ş-şarkıyye, (Beyrut: Dâru'l-Garbi'l-İslâmî, 1994) 2/531; Kâmil Muhyiddin Daûk, 'Ulemâunâ fî Beyrut, (Beyrut: 1970), 134-135.

13 Galâyînî, Dîvân, 116.

14 Galâyînî, Dîvân, 117-118.

15 Galâyînî, Dîvân, 38.

16 Örnek olarak bkz. Mustafa el-Galâyînî, "Fahru'ş-şebâb" (kaside), ez-Zehra, Haziran 1924, Y11: 4, Sayı: 2, s. 117-118; "Timsâlu'ş-Şeyh İbrahim el-Yâzicî” (kaside), ez-Zehra, Temmuz 1924, Y11 4, Say1: 3, s. 143; “Zikra'l-‘̂̂d fî nefsi'ş-şerîd” (kaside), ez-Zehra, Ağustos 1924, Y11: 4, Sayı: 4, s. 222. Aynı derginin Eylül 1924'te yayımlanan sayısında Galâyînî’nin Dîvân'ının yayımlanacağına dair bir haber ve eserin mukaddimesinden kısa bir parça neşredilmiştir. Bkz. "eş-Şi'r ve'l-hakîka" ve "el-Galâyînî ve dîvânuhu", ez-Zehra, Eylül 1924, Y1l 4, Say1: 5, s. 261-267; "el-Vahhâbiyye”, ez-Zehra, Ekim 1924, Y11 4, Say1: 6, s. 319-326; “eş-Şi'r fi’l-beyân ve'l-edeb" [Divanında neşredilen mukaddimede bir parça], ez-Zehra, Kasım 1924, Y11 4, Sayı: 7-8, s. 371-375. 
Hayfa'daki ikametinin ardından 1925'de Beyrut'a döndü ve el-Meclisu'lİslâmî başkanlığı, hâkimlik, İstinaf Mahkemesi müsteşarlığı gibi görevlerde bulundu. Şam'da el-Mecma 'u'l-'İlmî kurulduğu zaman üyeleri arasında yer ald1. Vefat edene kadar bu görevlerini devam ettirdi. 17 Haziran 1932 akşamı Beyrut'ta el-Kulliyyetu'ş-İ̀slâmiyye binasında Galâyînî onuruna büyük bir tören tertip edildi ve bu törene Lübnan'ın önde gelen siyasetçileri, edebiyatçıları ve ilim adamları katıldılar. ${ }^{17}$ Hayatının sonlarında bir deri hastalığına tutuldu. Yoğun tedavilere rağmen 1944 'te Beyrut'ta vefat etti ve el-Bâşûra kabristanına defnedildi. ${ }^{18}$ Vefatından sonra kütüphanesi Dâru'l-Kutubi'l-Lubnâniyye'ye intikal etmiştir. ${ }^{19}$

17 el-Câmi 'atü'l-'Arabiyye [Gazetesi], (Kudüs 15 Haziran 1932/Perşembe), 1. Aynı gazetenin 20 Haziran Pazartesi sayısında Galâyînî'nin onur töreninde İs'âf en-Neşâşî̂î’nin yaptığg konuşmanın tam metni verilmiştir. 23 Haziran Perşembe günkü sayısının 2. sayfasında tören programına özetle yer verilmiştir. Törende yaşanan ve ilgi çekici bulunan olaylardan biri yıllardır sarık ve cübbe giymeyen Galâyînî’ye bu törende tekrar sarık ve cübbe giydirilmesidir. el-Ma'riz dergisinde kendisiyle yapılan bir röportajda Galâyînî bu olayın hikayesini şöyle anlatır: “Sekiz yaşında Muhammed Zeydan'ın müdürü olduğu el-Medresetü'l-Vatanî'de sarık giydim. Haziran 1917 yılına kadar hep sarıklıydım. 32 yaşındaydım. Bu tarihte sarığı bırakıp fes giydim. Bir gece yarısı kapımı birisi çaldı. Uyandım ve iki polis gördüm. Beni polis müdürü Muhittin Bey’e götürdüler. Sebebini sorduğumda o sabah idam edilecek şehitlerin vasiyetlerini yazmak istediklerini söylediler. Gitmek istemedim. Beni zorla götürmeye çalışsalar da kabul etmedim ve deim ki "Ona şunu haber verin: Dini vazifeler için para alan bir sürü hoca var, bu iş için onlardan birisini seçsin”. Gittiler, sonra geri gelip tekrar beni götürmek istediler. Onlara şöyle dedim: İşte sarığım burada, çıkardım. Gelip onu alsın.” Sonra bir daha geri gelmediler. İş̧e bu tarihten sonra bir daha sarığımı giymedim.” İşte Galâyînî o gün çıkardığg sarığ1 1932'deki törende tekrar giymiştir (el-Ma'riz, Sayı: 1005, 26 Haziran 1932, , 19).

18 Edhem el-Cundî, A 'lâmü'l-edeb ve'l-fen, (Dimaşk: Matba'atü Mecelleti Savt Suriya, 1954) 1: 387; Hulusi K1lıç, "Mustafa el-Galâyînî", Türkiye Diyanet Vakfi İslam Ansiklopedisi, 31/301302.

19 Filip Di Tarrâzî, Hazâinu'l-kutubi'l- 'Arabiyye fi 'l-Hâfikayn, (Beyrut: Vizâretu't-Terbiyeti'lVataniyye, 1947) $1 / 261$. 


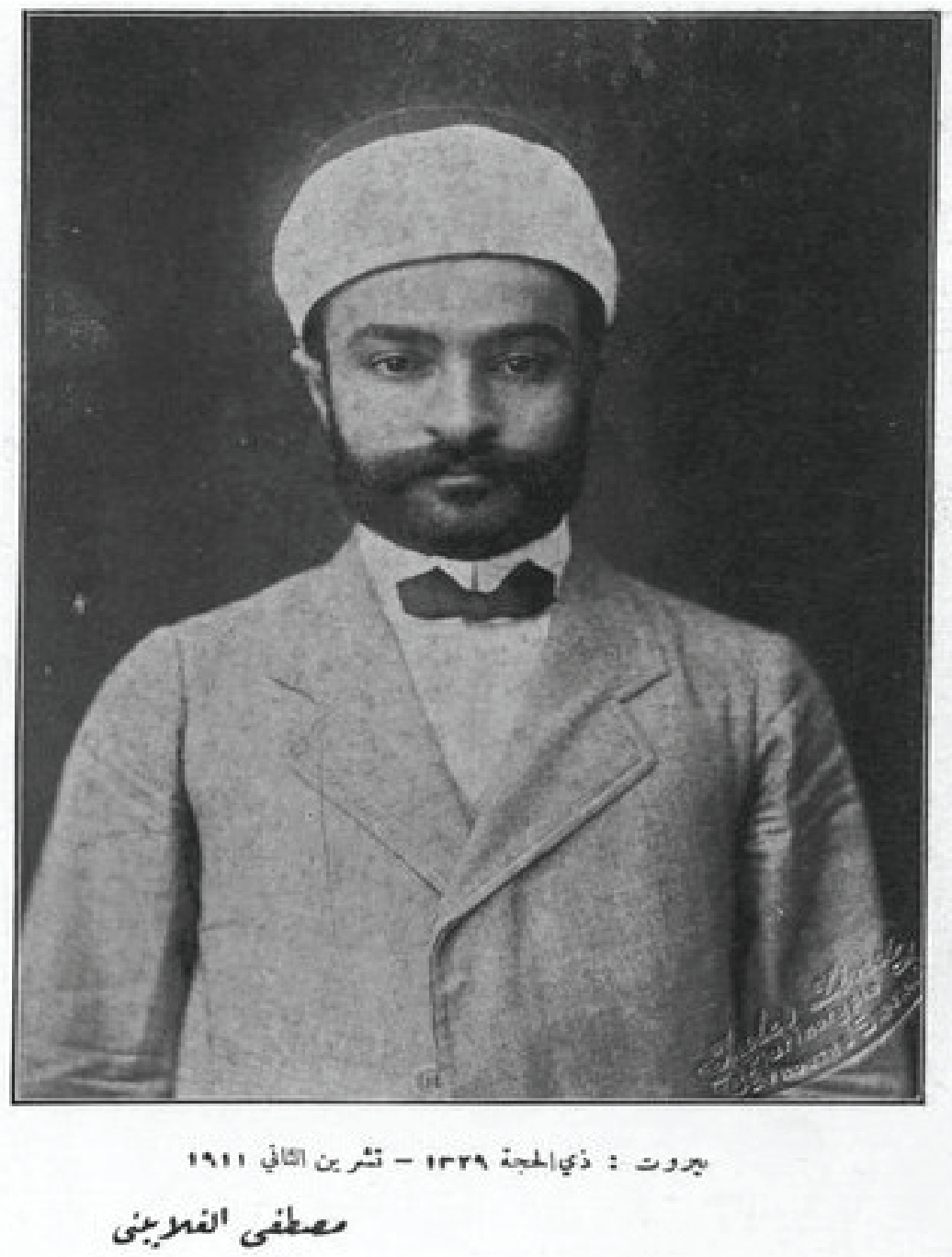

Resim 1. Mustafa el-Galâyînî 25 yaşında

(Erîcü’z-Zehr adlı kitabının iç kapağında yayımlanan bir fotoğrafi)

Mustafa el-Galâyînî, kaleme aldığı ders kitapları, gazete yazıları, çeşitli mahfillerdeki konuşmalarıyla sosyal hayata etkin bir şekilde katılan bir edebiyatçı ve ilim adamıydı. Dönemindeki tartışmalara dâhil olmaktan çekinmemiş, Lord Cromer'in Modern Egypt adlı kitabında İslam aleyhindeki iddialarına ve Nazîre Zeyneddin adıyla yayımlanmış es-Sufûr ve'l-hicâb adlı kitapta İslam'ın kadına bakışı ile ilgili iddialara cevap vermek üzere kitaplar kaleme almıştır. Uzun yıllar öğretmenlik yaparak genç nesillere geniş ufuklar açmaya, onlardaki milli ve manevî 
hamiyet duygusunu geliştirmeye çalışmıştır. ${ }^{20}$ Ezher'deki öğrenim yıllarından vefatına kadar basında makaleleri, şiirleri ve yorumlarıyla etkili olmuştur. ${ }^{21}$

Galâyînî, fikrî anlamda hocası Muhammed Abduh ve Muhammed Reşîd Rızâ'nın ıslahçı yaklaşımına yakın durmuştur. Makalelerini derlediği Erîcu'z-zehr adlı kitabını “Üstâdım, şarkın ve garbın âlimi ve filozofu, göz bebeği, Diyâr-1 Mısriyye'nin müftüsü Üstâd İmâm Şeyh Muhammed Abduh'un pakize ruhuna, hem benim hem de ümmet-i Muhammed'e olan iyiliklerinin bir nişâne-i itirâfı olarak ithaf ediyorum." sözleriyle Muhammed Abduh'a ithaf etmiştir. Ayrıca kitaplarında ve gazete/dergilerdeki yazılarında ona ve Reşîd Rızâ'ya atıflar yapmıştır. Reşîd Rızâ'nın çıkardığı el-Menâr dergisinde Cuma namazından sonra zuhr-1 ahîr namazı kılınmasıyla ilgili bir makale yazmıştır. ${ }^{22}$

\section{Eserleri}

Galâyînî, günümüzde daha çok Arap dili ve edebiyatı sahasındaki eserleriyle tanınmaktadır. Ancak dilbilgisi, aruz, şiir, edebiyat gibi konulardaki eserlerinin yanında sosyal konularda da çeşitli çalışmaları bulunmaktadır. Hayatı boyunca çeşitli gazete ve dergilerde makaleler neşretmiştir. Ayrıca şiirlerinin bir kısmını bu makalede incelenecek divanında bir araya getirmiştir.

Galâyînî’nin kitapları şöylece tanıtılabiliriz:

1. el-İslâm rûhu'l-medeniyye ev ed-dînu'l-İslâmî ve'l-Lord Kromer [Medeniyet Ruhu İslam Yahut İslam Dini ve Lord Kromer] (Beyrut 1326/1908): Galâyînî bu eserini, Britanya'nın Mısır Yüksek Komiseri Sir Evelyn Baring'in (Lord Cromer) Modern Egypt [Modern Mısır] adlı kitabında İslam aleyhinde serdettiği görüşlere cevap vermek amacıyla yazmıştır. Eserin girişinde yazarın Lord Cromer'e hitaben

20 Lübnanlı ünlü ressam Mustafa Ferrûh hâtıratında sanat hayatına başlamasında öğretmeni Mustafa el-Galâyînî’nin büyük etkisi olduğu söyleyerek şöyle bir hatırasını nakleder: "Çocukluk ve gençlik yıllarında ailem ve bazı hocalarım günah olduğunu söyleyerek resim yapmama karşı çıkar ve "Kıyamet gününde yaptığın suretlere can vereceksin." diye beni korkuturlardı. Ben de artık resim yapmayı bırakmıştım. Bir gün Mustafa el-Galâyînî hocamı gördüm. Bana "Resim nasıl gidiyor?" diye sordu. Ben de "Resim yapmayı bıraktım. Bana kıyamet günü yaptığım suretlere can vereceğimi söylüyorlar." dedim. Hocam gülümseyerek "Oğlum, sen resme devam et. Ben o suretlere can veririm." dedi. Ben de yeniden resme başladım. Süleyman Bahtî "75 'âmen 'alâ rahîli'ş-Şeyh Mustafa el-Galâyînî el-Beyrûtî el-Mütenevvir bi-erîci'l-ma'rife ve'nnahda”, Cerîdetü'l-Livâ, 5 Temmuz 2019.

21 Bkz. Âyide en-Neccâr, Sahâfet Filestîn ve'l-haraketu'l-vataniyye fì nusf karn 1900-1948, (Beyrut: el-Müessestu'l-Arabiyye li'd-Dirâsât ve'n-Neşr, 2005), 94, 135.

22 Mustafa el-Galâyînî, Risâletü'l-bid'a fî̀ salâti'z-zuhr ba 'de'l-cumu'a”, Mecelletü'l-Menâr, Şubat 1905, 7:941-948; (Mart 1905) 8/24-29. 
yazdığı uzunca bir kaside bulunur. Yazar eserde İslam'ın Lord Cormer'in iddia ettiği gibi terakkîye mani olmadığını akıcı bir dille ve tartışma üslubuyla kanıtlamaya çalışır. İslam'ın cihat, taassup, kısas, kölelik, kadın hakları gibi konulara yaklaşımını anlatır. $^{23}$

2. ed-Dîn ve'l-'ilm ve hel yunâfî'd-dîn el-'ilm [İlim ve Din: Din İlimle Çatışır mı?] (el-Mektebetü'l-Ehliyye, Beyrut, t.y.): Yazar elli sayfalık bu eserini Batı ülkelerinde tahsil gören gençlerin din-bilim ilişkisi konusundaki sorgulamalarına cevap bulmak üzere kaleme almıştır. Eserde din ile bilimin birbiri ile çelişmediğini ortaya koymaya çalışır. Bu bağlamda gençlerin Batı medeniyetinde gördükleri her şeyi kendi ifadesiyle "kör taklide" dayanarak benimseyerek kendi geleneklerine ve medeniyetlerine sırt çevirmelerinin ne kadar yanlış bir tavır olduğunu anlatır.

3. Lubâbu'l-hyyâr fî sîreti'l-Muhtâr [Hz. Muhammed'in Sîreti] (Beyrut 1323/1905): Yazarın genç öğrenciler için hazırladığı doksan sayfalık bu kitap özet bir siyer bölümü ve Hz. Peygamber'in kısa hadislerinden bazılarının alfabetik olarak sıralandığı bir seçkiden oluşmaktadır. Kitapta gençlerin kelime hazinelerini geliştirme amacı güdülerek yaygın olmayan bazı kelimeler özellikle kullanılmış bunların açıklamaları dipnotlarda verilmiştir.

4. Erîcu'z-zehr [Çiçek Kokusu] (el-Mektebetu'l-Ehliyye, Beyrut 1329/1911): Galâyînî, çeşitli makalelerden derlediği bu kitabını hocası Muhammed Abduh'a ithaf etmiştir. Eserde siyaset, Türk-Arap ilişkileri, eğitim öğretim, gençlik, kadının toplumdaki yeri vb. konularda makaleler bulunmaktadır.

5. Câmi'u'd-durûsi'l-'Arabiyye [Arapça Dersleri] (I-III, Beyrut 1330/1912). Galâyînî’nin en ünlü kitabıdır. Günümüze kadar onlarca baskısı çıkan kitap halen Arapça gramerinde başvuru kaynağı olma özelliğini korumaktadır.

6. ed-Durûsu'l-‘Arabiyye li'l-medârisi’l-ibtidâ'iyye [İlkokullar İçin Arapça Dersleri] (I-IV, Beyrut 1330/1912, 1422/2001): Müellifin ilk okullar için hazırladığı Arapça gramer kitabıdır. Kitapta çok sayıda örnek, geniş konu anlatımları ve alıştırma bulunmaktadır.

7. ed-Durûsu'l-‘Arabiyye li'l-medârisi’l-i'dâdiyye [İdâdîler İçin Arapça Dersleri] (I-IV, Beyrut 1330/1912, 1422/2001): Müellifin orta okullar için hazırladığı Arapça gramer kitabıdır ve ilk okullar için hazırladığı kitabın devamı mahiyetindedir.

23 Dönemin yazarlarından Ferîd Vecdî de Lord Cromer'e cevap olarak Lord Kromer ve'l-İslâm (Kahire 1326/1908) bir kitap kaleme almış, Muhammed Reşîd Rizâ el-Menâr dergisinde bir dizi makale yayımlamıştır: "Kitâb Mısr el-Hadîse Li- Lord Kromer” (el-Menâr, Nisan 1908/11:8111), “er-Red 'ale'l-Lord Kromer" (el-Menâr, May1s 1908/11:185-207), "er-Red 'ale'l-Lord Kromer” (el-Menâr, Haziran 1908/11:354-360). 
8. es-Sureyyâ 'l-mudî'e fi'd-durûsi'l-'arûziyye [Parlak Ülker Yıldız Takımı: Aruz Dersleri] (Beyrut 1319/1901, 1349/1930): İdadilerde aruz dersi alan öğrenciler için hazırlanmış bir ders kitabıdır. Eserin sonunda müellifin nazmettiği şiirlerden örnekler bulunmaktadır.

9. Ricâlü'l-mu'allakâti'l-'aşr [On Muallaka Şairli] (Beyrut 1331/1913, 1411/1990). Yazar bu eserinde cahiliye dönemi edebiyatının tarihinden kısaca bahsettikten sonra muallaka sahibi şairlerin biyografilerine ve şiirlerinden örneklere yer vermektedir.

10. 'Izatu'n-nâşi'în [Gençlere Nasihat] (el-Mektebetü'l-Ehliyye, Beyrut 1913): Galâyînî bu kitabında el-Müfíd gazetesinde Ebu'l-Feyyâz takma adıyla yayımladığı gençlere yönelik makalelerini bir araya getirmiştir. Ahlakî erdemlere dair edebî kısa yazılardan oluşan eserle yazar, hem gençlerin edebî zevklerini ve kelime hazinelerini geliştirmeyi amaçlamakta hem de ahlaklı bir nesil yetiştirmeye gayret etmektedir.

11. Târîhunâ ba'de'd-dustûr ve kablehû [Meşrutiyet'ten Sonra ve Önce Tarihimiz] (Matba'atu’t-Terakkî, Dimaşk 1915): Müellif, Dördüncü Ordu'da görev yaptığı sırada Hicaz Demiryolu'nun Bi'rü’s-seb'e ulaşması üzerine bir kaside yazıp bunu bastırmıştır.

12. Nazarât fi'l-luga ve'l-edeb [Dil ve Edebiyata Bakışlar] (Beyrut 1927): Müellifin İbrahim el-Münzir'in yanlış dil kullanımları hakkındaki Kitâbu'l-Münzir adlı eseri hakkındaki yorumlarını ve tashihlerini içermektedir.

13. Dîvânu'l-Galâyînî (Hayfa 1924) Galâyînî, Hayfa'da sürgünde ailesinden uzak bulunduğu sırada divanını tertip etmiş ve eserini burada 21 Temmuz 1924'te tamamlayarak yayımlamıştır. ${ }^{24}$ Gençlerin ve halkın şiirlerindeki bazı sözcükleri anlaması ihtimaline karşı dipnotlarda bunları açıklama ihtiyacını hissetmiştir. ${ }^{25}$ Galâyînî’nin Divan'1 yedi bölümden oluşmaktadır: Milli siyaset, hapishane hayatı, hamaset, edep ve hikmet, gazel, kitalar.

14. Nazarât fi's-sufûr ve'l-hicâb [Başörtüsü ve Açıklık Hakkında Görüşler] (Beyrut 1928): Nazîre Zeyneddin'in es-Sufûr ve'l-hicâb adlı kitabındaki iddialarına cevap olarak kaleme alınmıştır. Galâyînî’ye göre bu kitap aslında bir grup misyoner tarafından İslam'ı karalamak amacıyla kaleme alınmış ve Nazîre Zeyneddin'in adıyla yayımlanmıştır. Galâyînî eserinde kadının İslam'daki yeri konusundaki eleştirilere cevaplar vermektedir.

24 Galâyînî, Dîvân, 3.

25 Galâyînî, Dîvân, 5. 
15. Nuhbe mine'l-kelâmi'n-nebevî [Hadislerden Seçmeler] (Matba'atü'l-Misbâh, Beyrut 1929) Müellif bu eserinde kısa hadisleri alfabetik olarak sıralamış ve bilinmeyen kelimeleri dipnotlarda izah etmiştir. Lübâbü'l-hlyâr fí sîreti'l-Muhtâr adlı kitabının ikinci bölümü ile büyük oranda aynıdır.

16. et-Te'âvunu'l-ictimâ '̂̀ [Sosyal Dayanışma] (Beyrut, ts.) Sosyal dayanışmanın önemini konu edinen bir eserdir.

Galâyînî 1909-1910 yıllarında Beyrut'ta en-Nibrâs adlı bir dergi çıkarmıştır. Aylık bir dergi olan en-Nibrâs'taki yazıların tamamına yakını Galâyînî'ye aittir. Burada yayımlanan makalelerinden bazıları daha sonra kitaplaştırılmıştır. Dergide yayımlanan şiirlerden sadece bir kısmı divanında yer almaktadır. Dergideki yazıların büyük kısmı siyâsî ve edebî içeriklidir. Giriş sayısındaki açılış yazısında Galâyînî, uzun zamandır bir dergi çıkarma düşüncesine sahip olduğunu ancak Meşrutiyet' in ilanından sonra basım yayın üzerindeki denetimin rahatlamasıyla buna firsat bulduğunu dile getirir. el-İttihâdü'l-Osmânî gazetesindeki tecrübesinin kendisini bu konuda teşvik ettiğini ve bu işten her hangi bir maddi beklentisi olmadığını söyler. Maddi sıkıntılardan dolayı dergi ikinci yılının sonunda yayına son verir. ${ }^{26}$

Galâyînî, en-Nibrâs dergisinde gençlerin ahlâkî problemlerini ve çözüm yollarını ele aldığı Hadîsü Yahyâ b. Hâş̧im adlı bir romanını tefrika etmiştir.

26 Galâyînî, en-Nibrâs, 1 (Kânûn-i Sânî 1909), 1. 


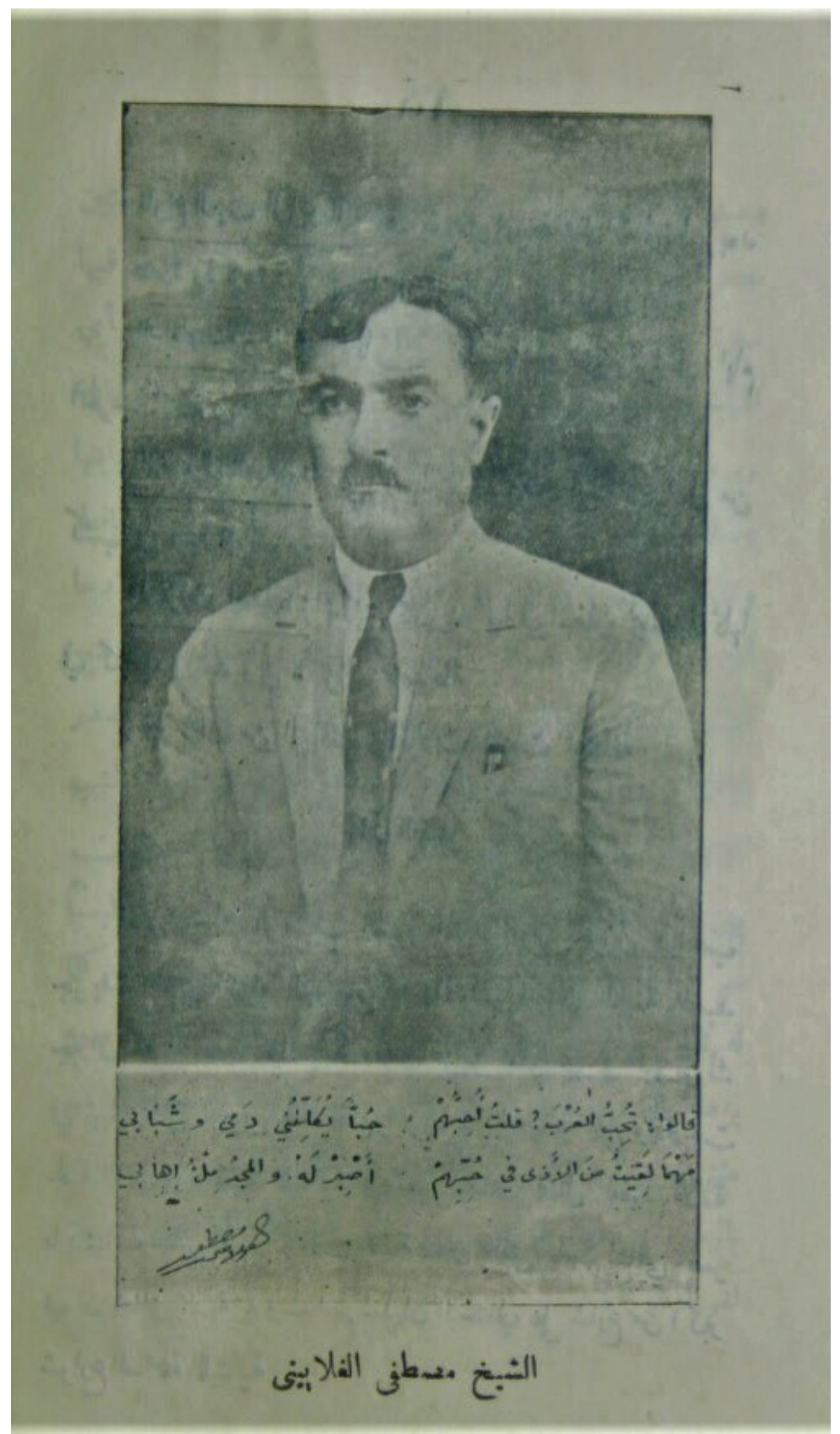

Resim 2. Mustafa el-Galâyînî'nin 1925 yılında Dîvân'ının tanıtımı ile birlikte Hayfa'da ez-Zehra dergisinde neşredilen bir fotoğrafı. El yazısı ile şiiri ve imzası ile birlikte. 


\section{Şiir ve Edebiyat Anlayıșı}

Galâyînî, daha çocukken şiire merak sardığını ve şiir yazmaya başladığını söyler. Okulda Tuğrâî'nin Lâmiyyetu'l-Acem 'i, Şenfera'nın Lâmiyyetu'l-Arab'1, İbnu'l-Verdî'nin ahlakî ögütler içeren Lâmiyye'si, İbn Dureyd' in Maksûre'si gibi kasideleri ezberleyip bunlardan etkilenmiştir. Daha sonra aruz tahsil etmiştir. Şiir konusunda tekellüf sahibi olmadığını, doğal olarak şiir nazmettiğini belirtmektedir. Bazen aylarca bir beyit bile söylemezken bazen bir ayda binlerce beyit yazmaktadır. Ruhsal durumuna göre aniden içinden geldiği gibi şiir söylemektedir. Gürültüde, sessiz mekânlarda, günün her saatinde şiir yazabildiğini ifade eder. ${ }^{27}$ Birinci Dünya Savaşı'ndan önce 2000 beyitlik bir divan oluşturmuş ve ona bazı kahramanlık şiirleri ekleyip bunun dışındaki bütün şiirlerini yok etmiştir. Ancak savaş sırasında bu divan da kaybolmuş, şiirlerin az bir kısmı kalmıştır. Savaş sırasında ve sonrasında da Şam, Beyrut ve başka yerlerde bazı şiirler kaleme almıştır ve bunları çeşitli gazete ve dergilerde neşretmiştir. 24 Temmuz 1920 yılında Kral Faysal'ın idaresindeki Şam, Fransızların eline düşünce Dimaşk'tan Beyrut'a dönmüş ve burada birkaç ay kalarak şiirler yazmış ve el-Hakîka gazetesinde Ebû Zuheyr el-Fevâidî imzasıyla yayımlamıştır. ${ }^{28} 1922$ 'de Beyrut'a döndükten sonra Fransızlar tarafından yakalanıp önce Beyrut'ta ardından Ervad adasındaki kaleye hapsedilmiştir. Bu günlerde şiir yazma isteği iyice artmış ve divanının bir parçası olan "Mahpusun Şiirleri”ni burada kaleme almıştır. Ervad Kalesi’nde tutuklu kaldığı sırada ailesinin gönderdiği eşyalar arasında eski şiirlerini bulmuş ve bunları burada düzenleme firsatını değerlendirmiştir. 16 Şubat 1924'te Fransız Askeri Hapishanesi'nde ikinci kez hapsedilince iki kaside daha yazıp divana ilave etmiştir. Hapisten çıkınca Hayfa'ya sürülmüştür. Burada da beş yüz beyte yakın şiir kaleme almıştır. İşte burada bulunduğu sırada Ervad Kalesi'nde ilk kez düzenlediği divanı tekrar gözden geçirme firsatı bulmuş ve onu yeniden düzenlemiştir. ${ }^{29}$ Eserine "Arap kalkınmasına dair" ve "Hapis hayatım" adlı iki bölüm eklemiş, birincisini ayrı bir kitap yapmak üzere eserden çıkarmıştır. Hapis hayatı ile ilgili bölüm ise divanda yer almaktadır. ${ }^{30}$ Divan'daki şiirlerin kahir ekseriyeti siyasi ve sosyal konularla ilgilidir.

Galâyinî, şiir ve edebiyata dair görüşlerini Divân'ının başına yazdığı bir giriş yazısıyla okuyuculara aktarmıştır. Bu teorik giriş bölümünü yazdığı sırada sürgünde bulunduğu için kitaplarına ulaşma imkânı bulamadığına, bu yüzden bu yazıda kendisinden önceki âlimlerin şiir hakkındaki görüşlerinden ancak hatırlayabildikleriyle yetindiğine, dolayısıyla daha çok kendi düşüncelerine yer

27 Galâyînî, Dîvân, 39- 38.

28 Galâyînî, Dîvân, 40.

29 Galâyînî, Dîvân, 41.

30 Galâyînî, Dîvân, 42. 
vereceğine işaret etmiştir. ${ }^{31}$ Yazar bu girişe şiir kelimesinin kökünü vererek başlar ve şiir köküyle ilgili kelimelerin "farkına varmak, anlamak ve hissetmek" anlamlarına sahip olduğunu belirtir. Arapların edebiyatın bu sanatına şiir adını vermeleri, şiirin önce algılanıp idrak edilmesi ardından elektrik akımı gibi onların iç dünyasına yansıyarak onları duygulandırması sebebiyledir. Ona göre kelimenin maddi boyutu tüy anlamındaki "şa ' $r$ " kelimesinden gelir. Tüylerin kökleri derinin altında gizlidir. İnsanın duyguları da içinde gizlidir. İnsandan bir tüy koparıldığı zaman büyük bir acı hisseder. İşte gönül de şiirle acı, zevk, sevinç, üzüntü, heyecan gibi duyguları yaşar. Şiir insanın içinde gizli olan şeyleri dışarı çıkarır. Soyut anlamları gösteren sözcükler başlangıçta maddi varlıklara işaret ederken sonraları soyut anlamlar kazanırlar. İlim, cehalet, akı1, delilik, iman, küfür, felah, hüsran, ülfet hep böyle sözcüklerdir. ${ }^{32}$

Ruhun bir duyguyu yoğun bir şekilde yaşaması şiirin tohumudur. Hayal onu geliştirir ve bir bitki filiz verir. İnfialler onu yetiştirir ve olgunlaştırır. Çiçekler açar, meyveler halini alır ve sonunda şiir olur. Özetle şiir ruhun dışavurumudur. Aslında şiire yatkınlık bütün ruhlarda bulunur. Ancak mizaca, duyguların çeşitliliğine, yaratıc1lı gücüne, tasvir becerisi ve ifade üslubunun yeterliliğine göre zayıf veya güçlü olur. Bazı ruhlar sadece etkilenirken bazıları bunu aşıp içlerinde coşan duyguları güzel bir kalıpla dile getirirler. ${ }^{33}$

Şiir halk lisanıyla veya bundan biraz daha yüksek bir seviyede yahut da çok yüksek bir dilde söylenebilir. Benzer şekilde fesahatin de aşamaları vardır. Beyanda üslubun kendine özgü bir yeri ve güzelliği bulunur. Sanat eserinde güç veren üslubun parlaklığıdır. ${ }^{34}$ Ifade üslubu serbest olabildiği gibi fikra ve seciler, vezin ve kafiyelerle kayıtlanmış da olabilir. Bu tür şiir zorlama olmadan, şairin doğasından kaynaklanmalı ve etkileyici bir armoni içermelidir. Ruhun ve duyguların yansıması olmalıdır. Eğer böyle değilse bu nesir veya nazımdır. Ruhu ve kanı olmayan bir iskelet veya meyvesiz bir ağaç gibidir. Şiirin kafiyeli ve vezinli oluşu onun ruhlarda ve kulaklarda daha fazla etki bırakmasını sağlar. Tınılarıyla ruhu okşar, nağmeleriyle gönülleri coşturur. ${ }^{35}$

Arap şiirinin temeli kafiyeli kısa söz öbekleri, secili parçalardır. Daha sonra recez ortaya çıkmıştır. Bu daha çok nesir şiire benzer. Vezinler ilk olarak develeri hızlandırmak için söylenen ezgilerde yer bulmuştur. Develer bu vezinlere uyan

31 Galâyînî, Dîvân, 6 .

32 Galâyînî, Dîvân, 8.

33 Galâyînî, Dîvân, 9-12.

34 Galâyînî, Dîvân, 10-11.

35 Galâyînî, Dîvân, 12-14. 
ritimlerdeki şarkılarla coşmaya meyyal hayvanlardır. Daha sonra aruz bahirlerinin sayısı on altıya kadar çıkmıştır. Bu bahirleri Halil b. Ahmed el-Ferâhidî (ö. 175/791) derleyerek, aruz ilmi diye bilinen ilmi ortaya koymuştur. ${ }^{36}$

Şiir Arap toplumunda çok yüksek bir seviyede iken yabancılarla karışan Araplar bu safiyet ve dil yeteneklerini kaybetmişlerdir. Cahiliye döneminde şair toplumunun önderi ve onların sözcüsü konumundaydı. Şair şiiriyle kavmi için savaşır, onun için nice cengâverlerin yapamadığı şeyleri yapardı. İslam'ın gelişi ve Kur'an'ın i'câzı ile şiir Arap toplumunda zayıfladı ise de Emevîler ve Abbâsîler ile birlikte yine eski canlılığını kazanmıştır. Endülüs şairleri de Arap şiirinin gelişmesinde büyük katkılarda bulunmuştur. ${ }^{37}$

Galâyînî, Arapların klasik şiir üslubundan ayrılarak Batının edebî tarzına meyleden bazı şairlerin bulunduğunu söyler. Ona göre bu, ya bu şairlerin doğru üslupları bilmemelerinden ya da Batılı tarzların daha iyi olduğunu düşünmelerinden kaynaklanmaktadır. Kendisi bunu "bulaşıcı bir hastalık" olarak görmekte ve Arap şiirine sızmasının önlenmesi gerektiğini belirtmektedir. Arap milliyetine bağlılıkları gereği bunu bırakmaları gerekir. Okullarda Arap dili ve edebiyatı dersinin verilmesi klasik üslubun korunmasını sağlayacaktır. ${ }^{38}$

Galâyînî, Arapların siyasi güçlerini kaybetmeleri ile birlikte edebiyatta da bir düşüş başladığı görüşündedir. Bu konuya dair Mutenebbî’nin şu beyitini örnek vermesi manidardır:

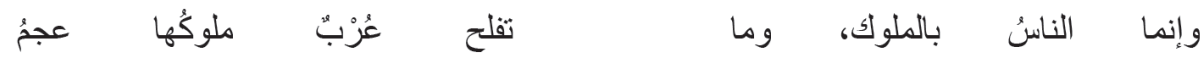

Insanlar hükümdarlarıyla birlikte vardırlar. Hükümdarları acem olan Araplar asla iflah olmazlar.

Ona göre bu durum Arap şiirinin zayıflamasına ve az sayıda şair yetiştirmesine sebep olmuştur. ${ }^{39}$

On dokuzuncu yüzyıl ile birlikte Şam, Mısır, Irak ve Tunus'ta Arap toplumunda bir hareketlenme başlamıştır. Bilimsel ve edebi reformda Misır diğer Arap beldelerine öncü olmuştur. Bunda Ezher Üniversitesi'nin büyük rolü vardır. Mısır'da Mehmet Ali Paşa'nın yaptığı reformlar, ilim ve sanata desteği, batıya öğrenciler göndermesi, gazeteler kurması, okulları yaygınlaştırması bu gelişmeye vesile olmuştur. Şiir de

36 Galâyînî, Dîvân, 15.

37 Galâyînî, Dîvân, 16-17.

38 Galâyînî, Ricâlü'l-mu 'allakâti'l- 'aşr: Kitâb edeb ve târîh ve luga, (Beyrut: el-Mektebetü'lAsriyye, 1998) 54-56.

39 Galâyînî, Dîvân, 18-19. 
bu gelişmelerden etkilenerek Mısır'da bir gelişim göstermiş, oradan diğer Arap ülkelerine geçmiştir. Şam diyarı uzun süre çeşitli politik sebeplerle bu gelişime ayak uyduramamıştır. Galâyînî’ye göre Mehmet Ali Paşa, Şam bölgesini de ele geçirerek Mısır'da yaptığı 1slahatları orada yapabilseydi, bu bölgede de edebiyat çok farklı bir konumda olacaktı. Arap dünyasındaki bilimsel ve sanatsal gelişmede Tunus'taki Zeytune Üniversitesi'nin de payı unutulmamalıdır. ${ }^{40}$

Galâyînî’ye göre şiir gerçeği yansıtmalı ve samimi bir duygunun ürünü olmalıdır. Yüksek duygulara ve değerlere hizmet etmelidir. Kişisel çıkar sağlamak, maddi imkânlar elde etmek için söylenen şiirler gerçek şiir, böyle bir kimse de gerçek şair sayılmaz. Para için kötü bir insanı yere göğe sığdıramayan, hiç tanımadığı bir kimsenin ölümünün ardından övgüler düzen bir insanın yaptı̆̆ ne kadar yanlıştır. Şiir ancak doğru bir ilhamın ürünü, gerçeklerin elçisidir. ${ }^{41}$ Galâyînî, şiiri toplumu eğitmek için bir araç olarak görmektedir. Bu amaçla toplumsal sorunları şiirlerinde dile getirmekten çekinmez, hatta şairleri buna davet eder. Edebiyat toplumun gözünü açmalı, manevî değerlerini yükseltmeli, hamiyetini coşturmalı ve ahlâkını güzelleştirmeye çalışmalıdır.

Şiirin hikmet, öğüt, fahr, hamaset, siyaset, gazel gibi pek çok konusu olabilir. Özellikle sıkıntılı dönemlerde siyasi şiirler şairin vicdanının bir yansıması olarak ortaya çıkar. Şair ülkesinin yaşadığı sıkıntılara bu şiirlerle çare arar. Halkını şiirleriyle uyarmaya çalışır. ${ }^{42}$ Galâyînî’ye göre Arap edebiyatı tarihi boyunca siyasi şiir genellikle asabiyet duygusuyla söylenmiş olsa da artık Arap milletini birleştirme gayesine hizmet etmelidir. Birinci Dünya Savaşı'ndan sonra Arap beldeleri yabancılar arasında paylaşılmış olsa da Araplar arasındaki millet bilinci şairler arasındaki etkisini kaybetmemiş ve onlar sayesinde diri tutulmuştur. ${ }^{43}$

\section{Galâyînî’nin Şiirlerinde Siyasi Temalar}

\section{İttihâd-ı Osmanî ve Arap Türk Kardeşliği}

Yirminci yüzyılın ilk yılları milliyetçi akımlar karşısında Osmanlı Devleti'nin tabileri arasındaki birliğin korunması adına Osmanlı birliği (İttihâd-ı Osmânî) ve İslam birliği (İttihâd-1 İslâm), Arap-Türk kardeşliği düşüncelerinin bazı şairler

40 Galâyînî, Dîvân, 21.

41 Galâyînî, Dîvân, 23-24.

42 Galâyînî, Dîvân, 29.

43 Galâyînî, Dîvân, 35-36. 
tarafindan dile getirildiği görülür. ${ }^{44}$ Galâyînî, İttihâd-1 Osmânî düşüncesini savunduğu dönemlerde kendi ifadesiyle "Osmanlı milleti tek yürektir." prensibine s1kı sıkıya bağlidır ve özellikle devletin iki ana unsuru olan Türkler ile Araplar arasındaki bu kardeşliği ve birliği korumak ve pekiştirmek için makaleler kaleme almıştır. ${ }^{45}$ Bu dönemde bazı Arapların Osmanlı Devleti'ne karşı bir Arap hilâfeti hevesine kapılmalarıyla ilgili olarak "Osmanlı milletine mensup Araplar böyle bir düşünceyi akıllarından bile geçirmeyecek kadar şerefli kimselerdir. Çünkü böyle bir idealin peşinden koşmanın, böyle bir gaye için çalışmanın hem Araplara hem de Türklere felaket getireceğinin farkındadırlar." demektedir. ${ }^{46}$ Galâyînî 1911 yılında el-İrfân dergisinde yayımladığı bir makalesinde İslam birliğini sağlama konusundaki emelini korumaya devam ettiğini söyler. ${ }^{47}$
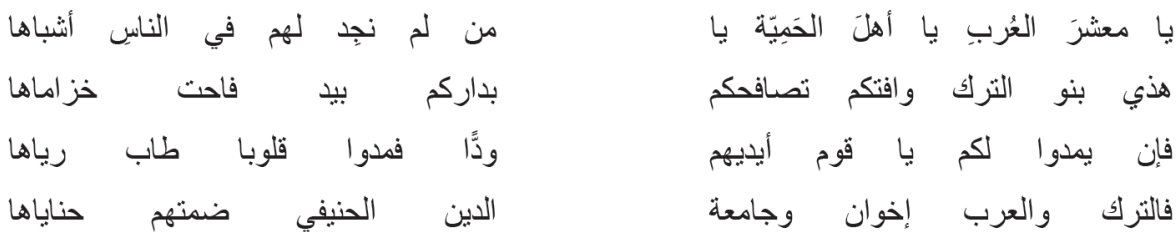

Ey Arap kavmi! Ey ehl-i hamiyyet! Ey kavm-i bî-misâl!

Işste Türkler geldiler, lavanta kokan ellerle tokalaşmak için size ellerini uzattılar.

Eğer size sevgiyle uzatırlarsa ellerini siz de hoş rayihalar saçan kalplerinizin kapısını açın.

Türkler ve Araplar kardeştir, din bağı onları birbirine bă̆lar. ${ }^{48}$

\section{Meşrûtiyet'in İlanı}

II. Meşrutiyet'in ilanı, Arap entelektüel çevrelerinde büyük bir etki bırakmış ve bu önemli hadise ve onu takip eden olaylar edebiyata özellikle de şiire yansımıştır. Bu dönemden sonra doğan özgürlük havasıyla Arap beldelerinde "istibdat" dönemini

44 Bkz. Muhammed Hüseyn, el-Itticâhâtu'l-vataniyye fi'l-edebi'l-mu 'âsır, (Kahire, Mektebetü'lÂdâb, 1954), 1/12-15.

45 Galâyînî’nin doğrudan bu konuda yazdığı makaleler şunlardır: "el-Arab ve’t-Türk", en-Nibrâs, 1.y1l/1 (22 Kanun-i Sânî, 1909) 5-14; "Harb aklâm lâ harb sihâm beyne'l-'Arab ve’t-Türk fî̀ hâzihi'l-eyyâm”, en-Nibrâs, 1.y11/9 (13 Teşrîn-i Sânî 1909) 321-331; “el-Ümmetü’1-İslâmiyye cism vâhid", en-Nibrâs, 2. yı1/6 (24 Haziran 1910) 206-210; "Sû'u't-tefâhum beyne'l-Arab ve’t-Türk yecib en yuzâl”, en-Nibrâs, 2. y11/8 (20 Teşrîn-i Evvel 1910) 333-336.

46 Galâyînî, "es-Si'âye ve'l-hilâfetu'l-Arabiyye fî̀ Dimaşk”, en-Nibrâs, 1. y11/8 (5 Teşrîn-i Evvel 1909) 300 .

47 Galâyînî, “el-Câmi 'atü'l-İslâmiyye”, Mecelletü'l-İrfân 15, (27 Temmuz 1911), 3/646.

48 Galâyînî, Erîcü'z-zehr, 15. 
eleştiren, özgürlük, eşitlik, adalet gibi kavramları büyük bir iştiyakla dile getiren şiirler yazılmıştır. ${ }^{49}$

II. Meşrutiyet'in ilanı, Galâyînî'nin sosyal hayatında önemli etki bırakmış ve şiirlerinde yankı bulmuş bir gelişmedir. İttihad ve Terakkî Cemiyeti’ne üye olan şair bu dönemden sonra en-Nibrâs dergisini kurmuş ve meşrutiyeti destekleyen bir siyasi çizgi izlemiştir. Meşrutiyetin ilanı ve buna götüren süreç hakkındaki düşüncelerini en-Nibrâs adlı dergisinde birçok makalede dile getirmiştir. Meclis-i Mebûsân'ın açılışı münasebetiyle Beyrut'ta İttihâd-1 Osmânî Kulübü'nde düzenlenen törende "Devr-i Sâbık ve Hâl-i Hâzır" başlıklı bir kasidesini okumuştur. Şairin matbu divanında bulunmayan bu kaside önce el-İttihâdu'l-Osmânî gazetesinde daha sonra el-İrfân dergisinde yayımlanmıştır. Şair bu kasidesinde meşrutiyetten önceki dönemde zulüm ve istibdâdın hüküm sürdüğünden, yöneticilerin halkın sorunlarına aldırış etmediklerinden bahseder ve şöyle der:

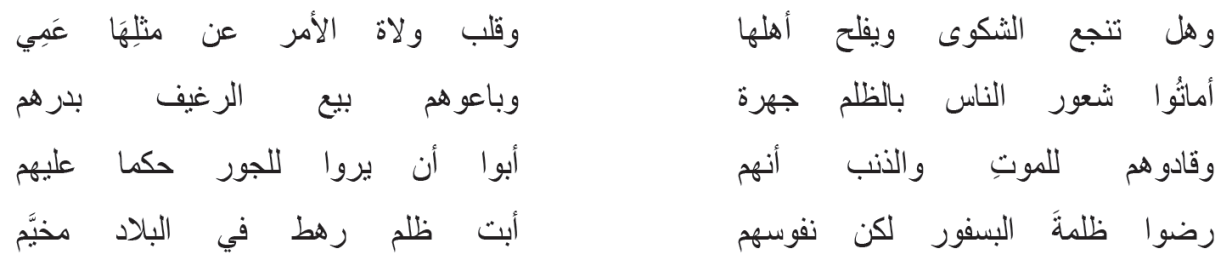

Şikâyet kâr eder mi? Iflâh olur mu ehli?

Olursa kör kilit gibi kapalı idarecilerin kalbi...

Ahalinin hislerini zulümle yok ettiler aşikâr.

Sattılar ekmek gibi bir kuruşa, hiç etmeden âr.

Sürüklediler onları acımadan ölüme

Razı gelmediler zulmün hükmüne diye.

Boyun eğseler de Boğaziçi'nin zâlimlerine!

Memlekete çöreklenmiş bu birkaç herife ne!

Şaire göre bu dönemde her yanı casuslar, jurnalciler kaplamış, insanlar haksız ithamlarla uzak yerlere sürgün edilmiştir. İstibdat sebebiyle zalim idareciler ve suçlular iş başına geçmiştir. Artık bu durum dayanılmaz bir hal alınca hamiyet sahibi vatanperverler (ahrâr) bu zulme dur demişlerdir:

49 Arap dünyasında İkinci Meşrutiyet ve Sultan Abdülhamid'in hal'i ile ilgili yazılan bazı şiirler için bkz. Muhammed Hüseyn, el-İtticâhâtu'l-vataniyye fi'l-edebi'l-mu 'âsır, 1: 27-35; Yusuf İzeddin, eş-Şi 'ru'l- 'trâkiyyu'l-hadîs ve eseru 't-teyârâti s-siyâsiyye ve'l-ictimâ 'iyye fîh, (Bağdat: Matba'atu Es'ad, 1960), 32-33. 

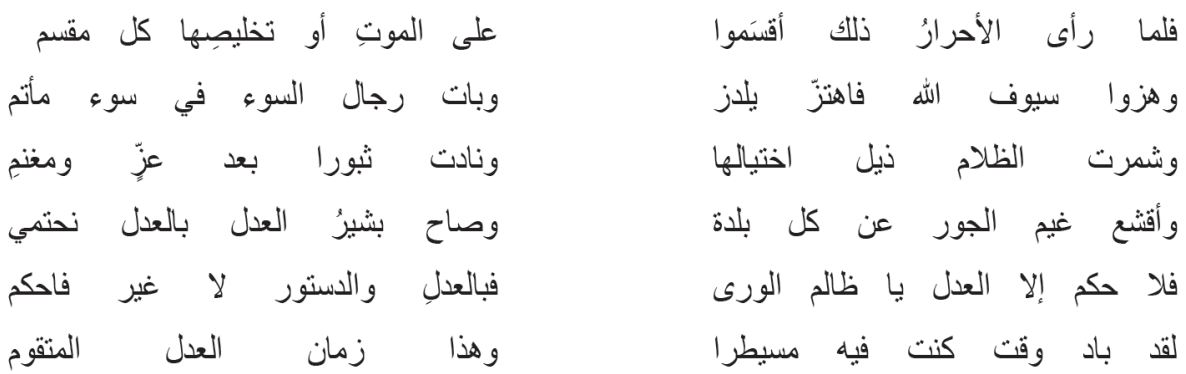

Görünce bu meş'ûm hali hürriyetperver yiğitler

Ölmek pahasına vatanı kurtarmaya and içtiler.

Allah'ın kılıçlarını salladılar, sarsıldı Yıldız

O zalimler matem içinde kaldılar yapayalnız.

Karanlık toplayarak kibir eteğini çıktı yola

Bunca yıllık şatafattan sonra işte kaldı yaya.

Dağıldı bütün yurttan zulmün bulutları

“Adaletin gölgesindeyiz" diye müjde nidaları...

Ey cevr ü cefa ile halkına eyleyen zulüm!

Anla artık adaletten başka kalmadı hüküm.

Artık adaletle ve yasa ile ülkeyi yönet.

Geçti senin devrin, geldi sarsılmaz devr-i adalet. ${ }^{50}$

Yukarıdaki beyitlerde görüldüğ̈ üzere şaire göre devr-i sâbık yani istibdât dönemi ile sonrası arasındaki en büyük fark adaletin tesis edilmiş olmasıdır.

Galâyînî, 1915 yılında Hicaz Demiryolu'nun Bi'ru's-Seb' beldesine ulaşması münasebetiyle nazmedip aynı yıl Dimaşk'ta yayımladığı Târîhunâ kable'd-düstûr ve ba 'dehû başlıklı bir kasidede konuyla ilgili benzer düşünceleri yeniden dile getirmiştir. Meşrutiyetten önce halkın özellikle de aydınların acınacak bir halde, büyük bir baskı altında yaşadığından şikayet eder. Pek çok kişinin jurnalcilerin ve casusların iftiraları sebebiyle haksız yere baskı gördüğünden bahseder. Meşrutiyet'in ilanıyla birlikte bir özgürlük ve adalet havası esmiştir. Ancak İttihad ve Terakkî’ye karşı meşrutiyet karşıtı güçler harekete geçse de Otuz Bir Mart Vakası olarak bilinen hadiseyle bunların önüne geçilmiştir. ${ }^{51}$

50 el-İrfân, 24 Eylül 1911, Say1: 19/3, s. 803-805.

51 Galâyînî, Târîhunâ kable'd-dustûr ve ba 'dehû, s. 4-6. 


\section{Otuz Bir Mart Vakası}

Galâyînî, Otuz Bir Mart vakası sürecinde örfî idâre kurulmasını desteklemiştir. Ona göre bu hadise devlet içinde çöreklenmiş olan ve istibdât idaresini geri getirmeye çalışan irticai bir urun sökülüp atılması anlamına gelmektedir. Bu konuyla ilgili yazdığı makalede Sultan II. Abdülhamid'i ettiği yemini bozmakla, şeriate muhalefetle, şer ‘î kaynaklara saygısızlıkla ve kanunları çiğnemekle suçlamıştır. ${ }^{52}$ en-Nibrâs'ta Otuz Bir Mart vakasıyla ilgili bir yazı neşredip bu yazıda Halil Halid Bey’ in konuyla ilgili makalesinin el-Mebâhis dergisinde neşredilen Arapça tercümesini özetle vermiştir. Sultan II. Abdülhamid'in tahttan indirilmesiyle sonuçlanan bu hadisenin Osmanlı Devletini baştan aşağı değiştiren bir olay olduğunu söylemektedir. Yine derginin aynı sayısında Ahmed Şevkî'nin ve Ma 'rûf er-Rusâfî'nin Otuz Bir Mart Vakası ile ilgili kasideleri ile el-Fevzü'l-mübîn başlıklı şiirini yayımlamıştır. ${ }^{53} \mathrm{Bu}$ kasidesinde Sultan II. Abdülhamid'e şöyle seslenmektedir:
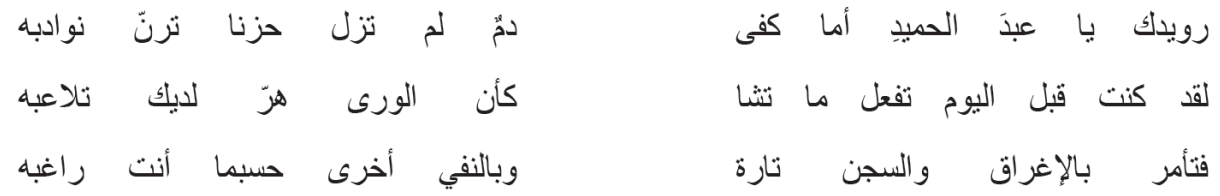

Yavaş ol ey Abdülhamîd, yetmez mi daha fazlası?

Döktügün kana hüzünle inleyen kadınların sedası

Bu günden önce yapıyordun dilediğin her şeyi

Halkla oynuyordun elindeki bir kedi gibi.

Keyfince emrederdin "Boğun, atın zindana!"

Bazen de sürerdin acımadan uzaklara.

وناوأت عزبا لا لتباري مقانبه

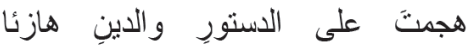

شرورا لها

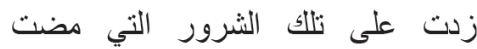

Hücum ettin düstura ve dine alay ederek

Asla diş geçirilemeyecek bir firkaya sataştın.

Önceki kötülüklerine ekledin yenilerini

Ihtiyar eder bunlar yeni doğmuş bebeği.

52 Galâyînî, “el-Hukmu'l-urfî”, en-Nibrâs, Beyrut 19 Haizran 1909, 1/6, s. 205.

53 Bu şiir için bkz. Galâyînî, "el-Fevzü'l-mübîn”, en-Nibrâs, Beyrut 19 Haizran 1909, cilt 1, say1: 6, s. 232-236. 
Görüldüğü üzere Galâyînî, Sultan II. Abdülhamid'e karşı ağır eleştirilerde bulunmakta, onun idaresini zulüm ve istibdat düzeni olarak isimlendirmektedir. Sultana karşı yönelttiği en büyük ithamlar, keyfi bir idare yürütmesi, muhalifleri karşısında adaletsiz hükümler vermesidir. II. Abdülhamid'i dine karşı savaş açan birisi olarak niteler. Bu durum Galâyînî'nin eleştirilerinde dini referans almaya çalıştığını gösterir. Şiirin devamında Mahmut Şevket Paşa'ya övgülerde bulunur ve yeni sultan Mehmed Reşad'a selam ve hürmetlerini arz eder. ${ }^{54}$ Galâyînî'nin Sultan Abdülhamid'e karşı takındığı olumsuz ve eleştirel tavrı devrin başka Arap şairlerinin şiirlerinde de görmek mümkündür. ${ }^{55}$

\section{Birinci Dünya Savaşı}

Birinci Dünya Savaşı ve savaş sırasında yaşanan hadiseler şiirlere konu olmuş, Arap şairler bu olaylar karşısında farklı tavırlar sergilemişlerdir. Şairlerin arasında savaş boyunca Osmanlı Devleti'ni savunan, Müslümanları cihada davet eden, Çanakkale zaferini ve devletin başarılarını kutlayıp itilaf devletlerini ve saldırgan tutumlarını eleştiren şiirler yazanlar olmuştur. ${ }^{56}$ Galâyînî, Birinci Dünya Savaşı sırasında Kanal Harekâtı'na hatip olarak katılmış ve Osmanlı Devleti'ni destekleyen şiirler yazmıştır. Yukarıda bahsi geçen Târîhunâ kable'd-dustûr ve ba 'dehû adlı kasidede Birinci Dünya Savaşı'na geniş yer ayırmıştır. Osmanlı Devleti’ne bağlılığını ve Arap milletinin düşmanlara karşı kanının son damlasına karşı savaşacağını şöyle dile getirmiştir:

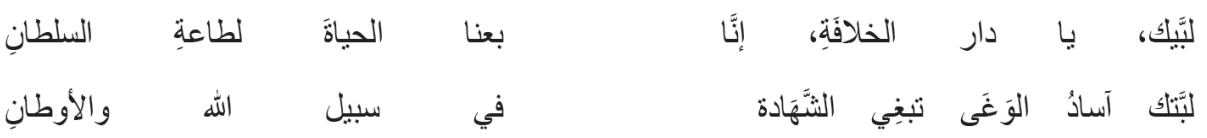

Emrindeyiz ey Hilafet yurdu, emret!

Biz canımızı sultana itaat için feda ettik.

Arzular şehadeti, hepsi birer aslan

Allah ve vatan yolunda, sendendir ferman!

54 Galâyînî, “el-Fevzü'l-mübîn”, en-Nibrâs, (Beyrut 19 Haizran 1909), cilt 1, sayı: 6, s. 234-335.

55 Örnek olarak Bkz. Yakup Göçemen, “Mısırlı Neo-Klasik Şair Veliyyüddin Yeken'in Şiirlerinde Sultan II. Abdülhamid”, Dokuz Eylül Üniversitesi Illahiyat Fakültesi Dergisi, 51, 2020, s. 243 245.

56 Bkz. Yusuf İzzeddin, eş-Şi 'ru'l-lrâkiyyu'l-hadîs, 75-85. 
Yazar, bu kasidede Osmanlı karşısında savaşa giren İttifak devletlerinden bahseder:

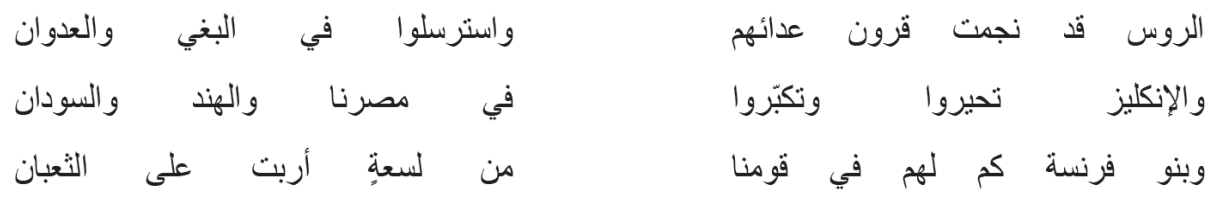

Rusların bize olan düşmanlıkları açıkça görülmüş̧ür.

Düşmanlık ve azginlıkta son hadde vardılar.

Ingilizler Misır' 'ımızda Hindistan ve Sudan'da

Şaşırıp kaldılar ve kibirlerine daldılar.

Fransızların milletimizde nice kötülükleri var.

Yılandan bile zehirli, kötüdür onlar. ${ }^{57}$

Şair Hicaz demiryolunun Bi'ru's-seb beldesine kadar ulaşmasını büyük bir hadise olarak görür ve Süveyş hamlesinde bir geri çekilme yaşansa da ordu komutanı Cemal Paşa sayesinde bu telafi edilecek ve zafer ele geçirilecektir.

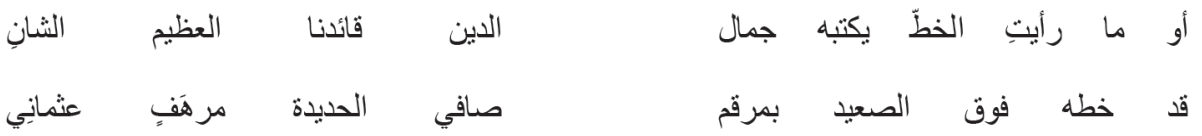

Görmez misin bu yazıyı şanlı komutanımız

Dinin cemâli Cemal Paşamız yazmıştır.

Bu tren yolu hattını parlak demirleri

Toprağın üstüne o dikmiştir. ${ }^{58}$

Bu sırada çoğu Şam Araplarından olan askerlerin büyük zorluk ve sıkıntılar çektiklerinden bahseden şair, toplardan birini çeken bir öküzün yorgunluk ve öfkeyle bir askere vurup öldürmesi üzerine bir kaside yazmıştır. Bu kasidede hayvanların bile zillet ve küçük düşürülmeye tahammül edemediğini, milletin de içinde bulunduğu vaziyetten silkinerek bu duruma karşı çıkması gerektiğini bildirmektedir. ${ }^{59}$

57 Galâyînî, Târîhunâ kable'd-dustûr ve ba 'dehû, 8-9.

58 Galâyînî, Târîhunâ kable'd-dustûr ve ba 'dehû, 14.

59 Galâyînî, Dîvân, 60-61. 
Şair "Bir Somun Ekmek İçin” başlıklı kasidesinde savaş sebebiyle halkın büyük sıkıntılar çektiğini, açlık, sefalet, hastalık vb. zorlukların insanları sarstığını dile getirmiş ve toplumu bu acıları bir nebze olsun hafifletmek için yardımlaşmaya çağırmıştır. ${ }^{60}$

1916'da Dimaşk'ta Fatih Sultan Mehmed ve İstanbul'un fethi hakkında bir kaside kaleme almıştır. Onun zorluklara karşı yılmayan mücadele azminin ve gemileri karadan yürütmesinin Arap toplumuna örnek olması gerektiğini dillendirmiştir:

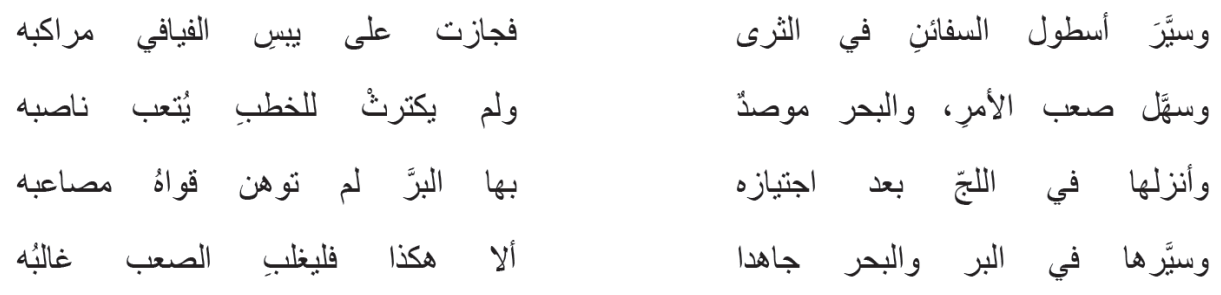

Gemileri donanmayı topraktan yürüttü

Kuru toprağı aşıp geçti

Zor işleri kolaylaştırdl, deniz zincirlerle kapatılmışken

Aldırmadı bu hale zorladı kendisini

Indirdi gemileri, karaları aştırıp

Güçleri zorluklar önünde eğilmedi.

Yürüttü gemileri çalışıp karadan ve denizden

Işte böyle yener zorlukları aşmak isteyen: ${ }^{61}$

\section{Osmanlı Devletinin Arap Beldelerinden Çekilmesi ve Arap Birliği Düşüncesi}

Birinci Dünya Savaşı'nı takip eden süreçte Arap şair ve düşünürlerin büyük kısm1, Arapları Arap milliyetçiliği etrafında kenetlenmeye davet etmişlerdir. ${ }^{62}$ Muhammed Hüseyin, Birinci Dünya Savaşı'nı Arap düşüncesinde "milliyetçilik ve vatanseverlik" kavramlarının dönüşümü açısından önemli bir nokta kabul eder. ${ }^{63}$ Mustafa el-Galâyînî, Osmanlı güçlerinin Şam'dan çekilmesi ile Şerîf Hüseyin'e katılmış ve Arapları onun sancağı altında birleşmeye davet etmiştir. Beyrut'ta

60 Galâyînî, Dîvân, 202-3.

61 Galâyînî, Dîvân, 164-165.

62 Ömer Dekkâk, el-İtticâhu'l-kavmîfi'ş-şi 'ri'l-Arabiyyi'l-hadîs, (Haleb: Mektebetu'ş-Şark, 1963), 40-43.

63 Muhammed Hüseyn, el-İtticâhâtu'l-vataniyye fi'l-edebi'l-mu'âsır, 1/d. 
1917'de yazdığ er-Râyetu'l- 'Arabiyye adlı şiirinde görüldüğü üzere bu tarihten sonraki söyleminin Osmanlı toplumuna veya İslam âlemine değil daha çok Arap milletine yönelik olduğu görülür. Şair bu şiirinde şöyle der:

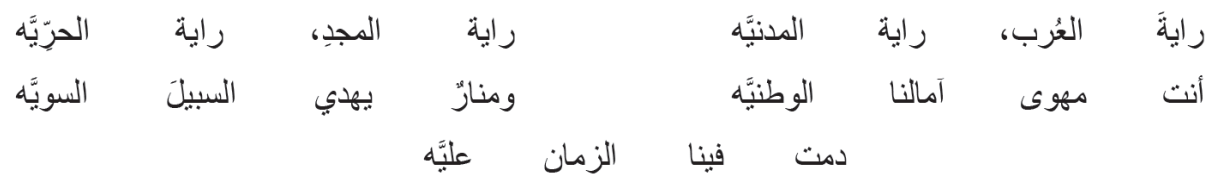

Arap sancağl, medeniyet sancağl

Şan şeref ve hürriyet sancağl!

Sen vatansever emellerimizin gayesi

Doğru yolu gösteren ışık kaynağ

Aramızda her zaman yükseklerde ol ${ }^{64}$

Galâyînî’ye göre Birinci Dünya Savaşı Arapların saflarını birleşmesini sağlayan bir vakıadır. Şerif Hüseyin etrafinda toplanan Arap milleti bu birlik sayesinde bağımsızlığına kavuşabilecektir. Ancak mezhep ve kabilecilik taassubu gibi sebeplerle Arap birliğini sarsabilecek tartışmalar ortaya çıkmaya başlamış, bu da şairin duyduğu rahatsızlığı açıkça ifade etmesine ve Arapları yeniden saflarını birleştirmeye davet etmesine sebep olmuştur. Beyrut'ta 1918'de kaleme aldığg 1 bir şiirde Türklerin bölgeden çekilmesinden sonra özellikle Şam bölgesinde ve Beyrut'ta Müslüman ve Hıristiyan Araplar arasındaki anlaşmazlıkların iyice arttığını ve kurulacak hükümetin şekli hakkında ayrıldıklarını ifade etmektedir. Bunun üzerine gazetelerde çıkan yazılara cevaben birlik çağrısı yapmak üzere bir kaside kaleme almıştır. Şaire göre fikir ayrılıkları Arapları karanlıkların içine çekecektir. Şair, Arapların hatta Doğu milletlerinin en büyük derdi olan siyasetten şikâyet etmektedir. $^{65}$

64 Galâyînî, Dîvân, 47.

65 Galâyînî, Dîvân, 63-64. 


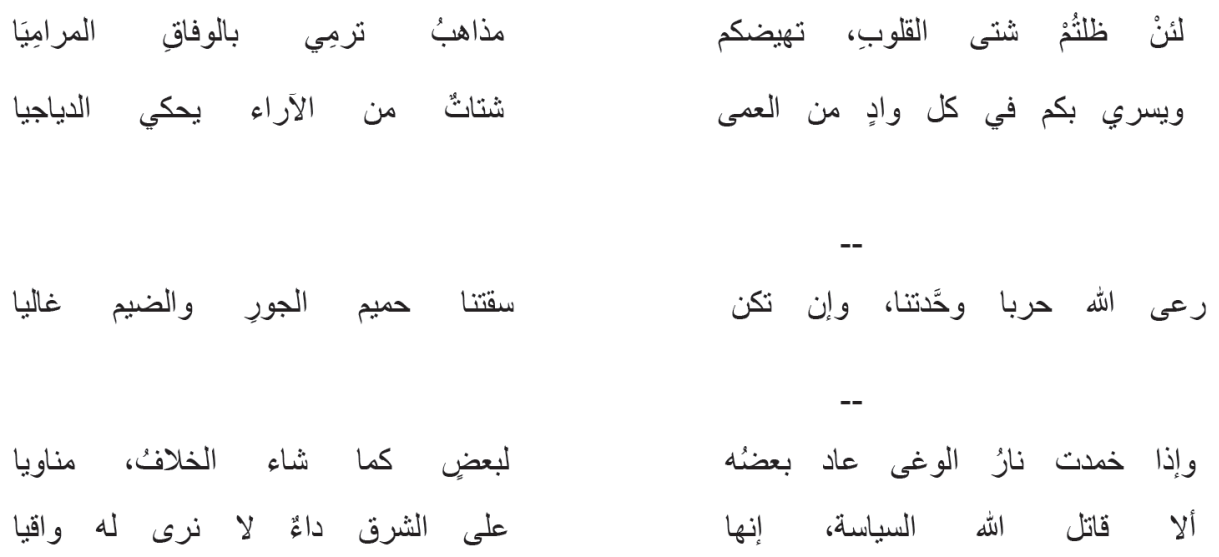

Kalpleriniz soğuduysa birbirinizden

Ümidinizi kesin tek yürek olup ulaşacağınız emelinizden

Bu fikir ayrllıkları sokacaktır sizi vadilere

Önünüzü göremezsiniz orada, benzer karanlık gecelere

Yaşadı̆̆ımız bu harpten razı olsun yüce Mevlâ

Birleştirdi bizi, zulüm ve zorluklarl yaşasak da.

Ama savaşın ateşi sönünce insanlar

Yine düştüler birbirlerine, yine düşmanlar.

Siyaset denen şeyi kahretsin Yüce Mevlâ

Budur şarkın derdi, kurtulamaz ondan asla.

Galâyînî taassup ve ucuz siyasi emellere ve maddi çıkarlara tamah ederek milleti bölmeye, nifak çıkarmaya çalışanlara pek çok makale ve şiirinde karş1 çıkmıştır. Sonraki yıllarda bile bu vurgusunu korumuş ve bulduğu her firsatta bunu dillendirmiştir. Şerîf Hüseyin'in vefatı münasebetiyle 1931'de yazdığı bir mersiyede şöyle demektedir:

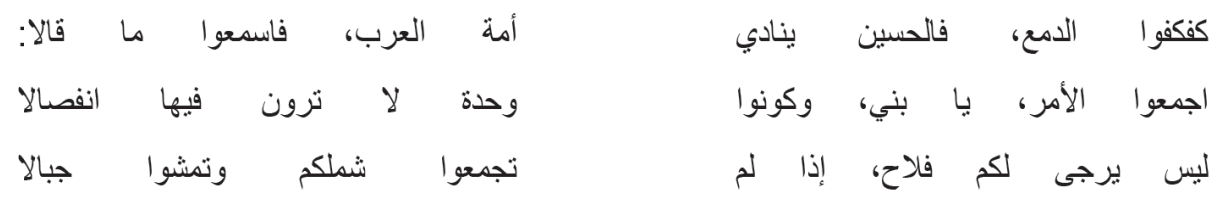


Göz yaşlarınızı silin! Sesleniyor Hüseyin,

Ey Arap milleti söylediğini dinleyin!

Birleşin, oğullarım, birlik olun

Sakın bir daha ayrılık görmeyin.

Ĕger saflarınızı birleştirmezseniz ve gayret etmezseniz

Iflah olmaz, yükselemezsiniz. ${ }^{66}$

Arapların şanlı günlerini yâd ettiği, onların hatırasına ağladığı bir şiirinde Arapların halinden şikâyet etmekte ve zillet içinde yaşamaktan vazgeçmelerini ve atalarının mirasına layık olmalarını ögütlemektedir. ${ }^{67}$ Ona göre kasideler yazmak, şikâyet dilekçeleri kaleme almak artık fayda vermez. Harekete geçmek lazımdır.

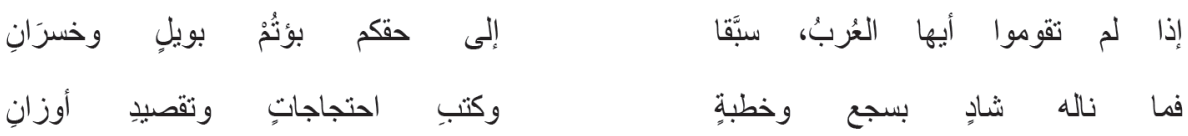

Ĕger Araplar kalkıp hakkınızı almak için koşmazsanız siz feryad u figan ve hüsran içinde kalacaksiniz.

Seci ve hutbelerle, dilekçeler ve kasideler yazmakla bir yere varamazsınız. ${ }^{68}$

Şair 1920'de düzenlenen ve Arap devletlerinin İngiltere mandaterliği altına girmesinin kararlaştırıldığ 1 San Remo konferansı ile ilgili bir kaside kaleme almıștır. Bu kasidede konferansta alınan kararların geçerli olmasının mümkün olmadığını, istiklalden başka bir şeye razı olmayacaklarını açıkça ifade etmiştir. Eğer bağımsızlıkları verilmezse Arapların kendilerini savunacağını söylemiştir. ${ }^{69}$ Konferansta geçen "himaye" ve "vesayet" kelimelerin Arap ülkelerine atılan oklar olduğunu ifade etmiş ve savaş sırasında Araplara verilen sözlerin nerede olduğunu sorarak Batılı güçleri hainlikle suçlamıştır. ${ }^{70}$

\section{Türk İstiklal Savașı ve Mustafa Kemal}

Galâyînî, Türkiye'de yürütülen bağımsızlık mücadelesini takip etmiş ve bu mücadelenin Araplar için de örnek olması gerektiğini dile getirmiştir. Bu bağlamda aşağıda bir kısmını vereceğimiz şiirinde görüleceği üzere Mustafa Kemal Paşa, onun için dağılmış bir milleti toplayıp düşmanla mücadele eden örnek bir komutandır.

66 Galâyînî, el-Hayât Gazetesi, Kudüs sayı: 355; 14 Temmuz 1931, s. 2.

67 Galâyînî, Dîvân, 72-74.

68 Galâyînî, Dîvân, 74.

69 Galâyînî, Dîvân, 76.

70 Galâyînî, Dîvân, 77. 
Vatanın perişan halini görmüş ve milleti tekrar toparlayarak düşmana karşı harekete geçmiştir:
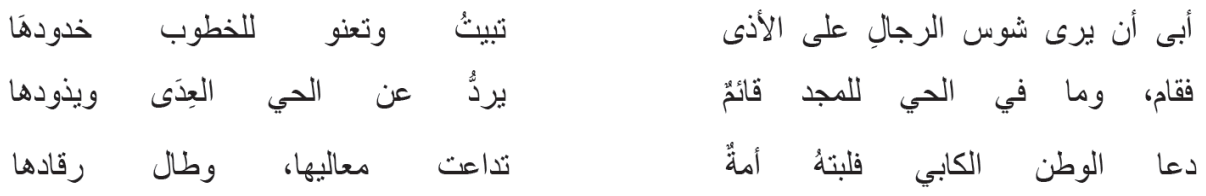

Vatanın gençlerinin eziyet edildiğini ve hor görüldüğü görmeyi kabul etmedi.

Kalktı, yurtta hiç kimse kalkmaz iken o harekete geçti ve orayı düşmandan korumaya kalkıştı.

Ezilen vatanı çağırdı ve uzun zamandır uyuyan millet onun çağrısını kabul etti. ${ }^{71}$
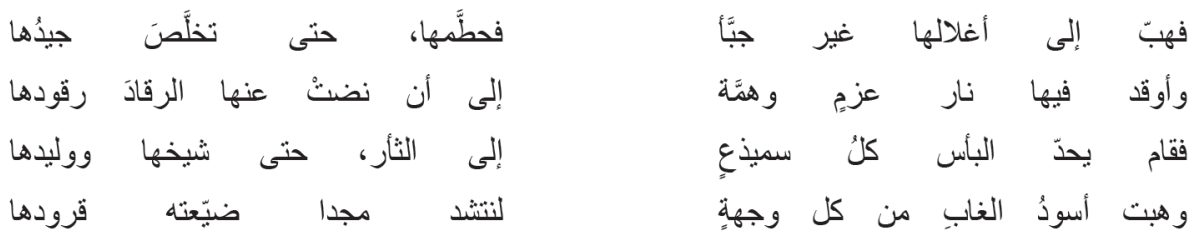

Hiç aldırmadan zincirlere koştu ve onları paramparça etti ve boynunu kurtardı.

Halkının içinde azim ve himmet ateşini yaktı, uyuşukluk ondan kalkana kadar uğraştı.

Ihtiyar, çocuk herkes öç almak için kahramanca mücadele etti.

Ormanın aslanları her bir yandan kalktılar ve maymunların kaybettiği şan ve şerefi geri getirdiler. $^{72}$

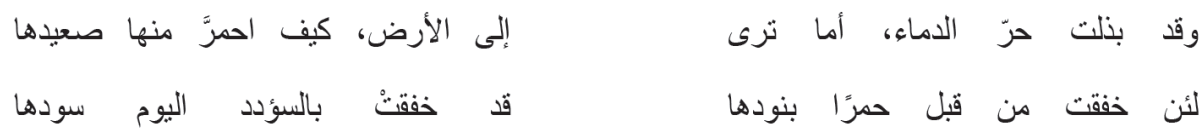

Kanını feda etmiştir. Görmez misin o vatanı nasıl toprağı şehit kanıyla kızarmış?

Bentleri şehit kanlarıyla kırmızı aktıysa şimdi şan ve şerefle bayră̆ı dalgalanıyor. ${ }^{73}$

71 Galâyînî, Dîvân, 80.

72 Galâyînî, Dîvân, 81.

73 Galâyînî, Dîvân, 81. 
Galâyînî, Mustafa Kemal ve Anadolu insanının yaptığı fedakârlığg ve gösterdiği başarıyı Arap milletine örnek olarak göstermektedir:

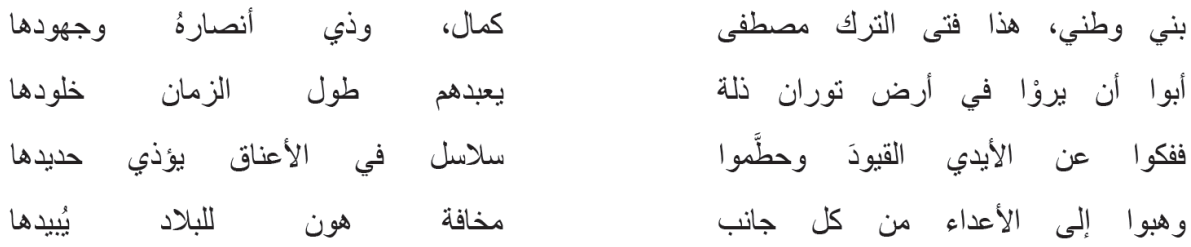

Vatanımın evlatları, İște Türklerin yiğidi Mustafa Kemal!

İşte arkadaşları ve işte harcanan çabalar!

Turan yurdunda zillet görmeyi, ebediyen köle olmayı reddettiler.

Ellerindeki zincirleri çözdüler ve boyunlarındaki kementleri parçaladılar.

Vatanın elden gitmesi korkusuyla her taraftan düşmana saldırdılar. ${ }^{74}$

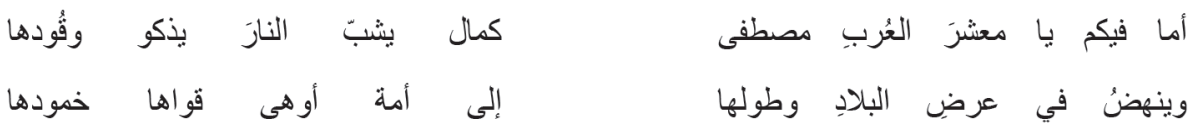

Ey Araplar! İçinizde mücadele ateşini tutuşturacak bir Mustafa Kemal yok mu?

Gücü zayıflamış, bitkin düşmüş Arap yurdunun dört bir tarafindaki milleti kaldıracak?

\section{Fransızlara Karşı Mücadele ve Hapishane/Sürgün Yılları}

Birinci Dünya Savaşı'nın sona ermesinin ardından Arap ülkeleri İngilizler ve Fransızlar arasında bölüşülmüştür. Yazar bu sırada Beyrut'ta bulunmaktadır. Şam'a Mister Kurein'in başkanlık ettiği Amerika heyeti kamuoyu yoklaması için geldiğinde Galâyînî heyetlerden biri ile birlikte bu şahısla konuşmaya gitmiş ve bir konuşma yapmıştır.

O sırada el-Mufid gazetesinin sahiplerinden arkadaşı Hayreddin Zirikli de ondan bu konuşmasını talep ederek bunu gazetesinde yayınlamıştır. Bu konuşma metnini gören Fransızlar Galâyînî’yi yakalama kararı almışlardır. Emir Faysal hükümetinin merkezi olan Dimaşk'a kaçan Galâyînî orada Genel Divân-ı Resâil idareciliğini üstlenmiştir. O dönemde insanlar Şam'da manda ve himayeye tamamen karşı çıkmışlardır. Britanya aynı dönemde bazı kimselerin Amerikan Mandasını kabul etmesi için çalışmaya başlamıştır. Bağımsız bir devlet olmayı arzulayan Lübnanlıların bu isteği bazı Batı devletlerinden destek görmüştür ve sömürgeciliği tatmalarına sebep olmuştur. Dimaşk Fransızların eline düşünce Galâyînî tutuklanmış ve bir müddet sonra serbest bırakılarak Dimaşk'ı terk etmesi ve

74 Galâyînî, Dîvân, 83. 
Beyrut'a gitmesi söylenmiştir. Beyrut'ta birkaç ay kaldıktan sonra Emir Abdullah'ın Amman'a geçtiğini öğrenince Beyrut'tan çıkıp Nisan 1921'de Amman'a gitmiştir. Orada Dımaşk'ta olduğu gibi Divân-1 Resâil başkanlığına getirilmiştir. Galâyînî 1922'de ailesini getirmek üzere Beyrut'a dönmüss bu sırada Amerikan heyeti olayı yaşanmıştır. ${ }^{75}$ Beyrut'ta Dâhiliye müdürü Esad Hurşid'e suikast düzenlenmiş, pek çok Beyrutlu ve Şamlı olayın ardından tutuklanmıştır. Beyrut'ta tutuklananlar arasında yazar da bulunmaktadır. 9 Nisan'da Beyrut'taki evi basılmış ve oradan alınarak hapse atılmıştır. İki ay Beyrut’taki polis merkezinde beş ay Ervad adasındaki kalede toplam yedi ay tutuklu kalmıştır. ${ }^{76}$

Serbest bırakıldıktan sonra Beyrut'tan sürülmüş önce Amman'a gitmiş ve Emir Talâl'ın hocalığını yapmıştır. Burada 13 aydan biraz fazla kalmıştır. Sonra bu görevinden istifa etmiş ve Şubat 1924'te Beyrut'a dönmüştür. Beyrut'a varır varmaz Fransızlar tarafindan yeniden tutuklanmış, Beyrut'ta hücre hapsine atılmış ve 15 gün burada kalmıştır. ${ }^{77}$ Hapisten çıkarılınca Filistin'e sürgüne gönderilmiş ve Hayfa şehrine yerleşmiştir. ${ }^{78}$

$\mathrm{Bu}$ süreçte milli hisleri ayakta tutacak şiirler kaleme almıştır. Arap milletinin başından yabancı işgali belasını def edecek yeterliliğe sahip olduğunu şayet uyanmazlarsa başlarına daha büyük felaketlerin geleceği konusunda uyarmıştır. ${ }^{79}$ 1921'de Amman'da söylediği bir şiirde Arapları Şam'a yardıma koşmaya davet etmektedir:
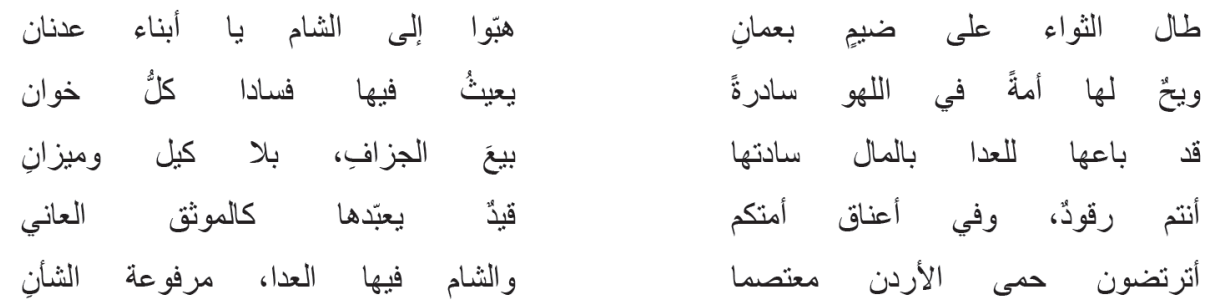

Amman'da sıkıntı içinde kalmamız ne kadar uzun sürdü. Ey Adnan evladı, kalkın Şam'a koşun.

Eğlence içinde oyalanan ve fesat içinde oynayan hainlere vahlar olsun.

Mal ile şerefini düşmanlara satmış, hiç tartıp ölçmeden.

Siz uyurken milletinizin boynuna bağ geçirmişler ve onu köle yapıyorlar.

Şam düşman elindeyken Ürdün'de yaşamaya nasıl razı olursunuz? ${ }^{80}$

75 Galâyînî, Dîvân, 116.

76 Galâyînî, Dîvân, 117-118.

77 Galâyînî, Dîvân, 120.

78 Galâyînî, Dîvân, 120.

79 Galâyînî, Dîvân, 88.

80 Galâyînî, Dîvân, 89. 
1922'de Ervad'da hapishanedeyken Irak halkını Fransızlara karşı mücadelesinde Şam'a yardıma koşmaya çă̆ırır:

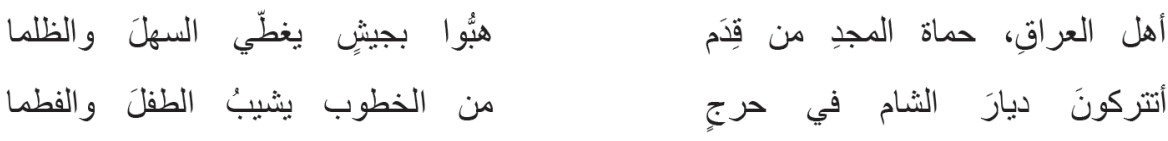

Ey Irak halku! Ey eski çağlardan beri şan ve şerefin hâmîleri!

Ovaları dolduran bir ordu ile yola çıkın.

Şam beldesini bebekleri ihtiyarlatacak dehşetli bir halde mi bırakacaksınız?

Amman'a geldiği zaman Melik Hüseyin'e 1924'te bir kaside sunmuş ve Arapların ümidinin kendisine bağlı olduğunu ifade etmiştir:

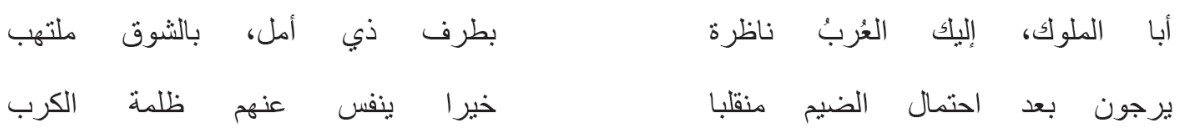

Ey krallarin atas!! Araplarnn gözü senin üstünde!

Sana büyük ümitlerle, iştiyakla yanarak baklyorlar.

Bu büyük cefa ve meşakkatleri çektikten sonra

Bu gam ve keder bulutlarını dağıtacak bir hayır bekliyorlar.

\section{Sonuç}

Yukarıda şiirlerinden verdiğimiz örneklerden ve siyasi ve sosyal alandaki faaliyetlerinin serencamından anlaşıldığı üzere Mustafa el-Galâyînî, oldukça çalkantılı bir dönem olan yirminci asrın ilk yarısında Arap edebiyat hayatında yer almış ve dönemine ışık tutacak eserler kaleme almıştır. İttihat ve Terakkî’nin politikalarına, Osmanlıcılık düşüncesine yakın bir tutum sergilemiş, II. Meşrutiyet'in ilanı ve II. Abdülhamid'in tahttan indirilmesinden memnuniyetini şiirlerinde dile getirmiştir. Birinci Dünya Savaşı'nda Osmanlı ordusunda görev almış ve Osmanlı Devleti Arap coğrafyasından çekilene kadar devletin kurtuluşu için şiirlerinde Müslümanları saflarını birleştirmeye davet etmiştir. Daha sonra Şerîf Hüseyin'in yanında yer almış ve onun etrafında Arap millî bilincinin ve birliğinin oluşmasını sağlayacak bir mücadele içerisine girmiştir. Dünya savaşını takip eden süreçte işgal güçlerine karşı mücadelede aktif rol almış bu sebeple Fransız yönetimi tarafından hapsedilmiştir. Arapların sömürgecilere karşı mücadelelerinde Mustafa Kemal önderliğinde Anadolu'da yürütülen millî mücadelenin örnek alınması gerektiğine dair bir kaside kaleme almıştır. Vefatına kadar Lübnan'da çeşitli vazifeler almış ve eserler vermeye devam etmiştir. 
Galâyînî, şiirlerinde şekil yönünden klasik geleneği devam ettirme taraftarı olmuştur. Dilbilgisi ve aruz konusunda kitaplar telif edecek derece bilgi sahibi olduğundan şiirin yapısı güçlüdür. Ona göre yaşadığı çağda şiir halkı aydınlatmak ve yanlışlıkları düzeltmek için kullanılmalıdır. Bu sebeple kendisinin de daha çok siyasî ve sosyal konularda şiir yazdığı söylenebilir.

Osmanlı Devleti'nin yıkılma sürecine girdiği dönemin, Arap vilayetlerindeki edip ve aydınların Osmanlı'ya karşı tutumlarının daha iyi anlaşılması için oldukça etkin olan siyasi edebiyatına ait ürünlerin incelenmesi bir zarurettir. Bu makalede yapılmaya çalışılan sadece bu edebî faaliyetin önemli figürlerinden birisi olan Mustafa el-Galâyînî’nin şiirleri üzerinde bir değerlendirme çabasıdır.

Hakem Değerlendirmesi: Diş bağımsız.

Çıkar Çatışması: Yazar çıkar çatışması bildirmemiştir.

Finansal Destek: Yazar bu çalışma için finansal destek almadığını beyan etmiştir.

Peer-review: Externally peer-reviewed.

Conflict of Interest: The author has no conflict of interest to declare.

Grant Support: The author declared that this study has received no grant support.

\section{Kaynakça/References}

el-Câmi 'atu'l- 'Arabiyye [Gazetesi], (Kudüs 15 Haziran 1932/Perşembe)

Cundî, Edhem, A 'lâmu'l-edeb ve'l-fen, Dimaşk: Matba'atü Mecelleti Savt Suriya, 1954.

Dekkâk, Ömer, el-İtticâhu 'l-kavmî fi'ş-şi 'ri'l-Arabiyyi'l-hadîs, Haleb: Mektebetu'ş-Şark, 1963.

Filip Dî Tarrâzî, Hazâinu 'l-kutubi 'l- 'Arabiyye fi'l-Hâfikayn, Beyrut: Vizâretu'-Terbiyeti'l-Vataniyye, 1947.

Galâyînî, Mustafa, Risâletu'l-bid'a fî̀ salâti'z-zuhr ba ‘de'l-cumu'a”, Mecelletu'l-Menâr, Şubat 1905, 7:941-948; (Mart 1905) 824-29.

Galâyînî, “el-Câmi'atu'l-İslâmiyye”, Mecelletu'l-İrfân 15, (27 Temmuz 1911), 3:646.

Galâyînî, Dîvânu'l-Galâyîn̂̂, Hayfa: el-Matba'atu'l-‘Abbâsiyye, 1925.

Galâyînî, Erîcü'z-zehr, Beyrut: el-Matba'atu'l-Ehliyye, 1911.

Galâyînî, el-İslâm rûhu'l-medeniyye, Beyrut: 1907.

Galâyînî, “el-Hukmu'l-urfi”, en-Nibrâs, Beyrut 1. yı1/6 (19 Haizran 1909), s. 205.

Galâyînî, "Serikatu Kındîl (Kasîde)", ez-Zehra, Eylül 1925, y1l 5, sayı: 3, s. 137-138.

Galâyînî, “es-Si'âye ve'l-hilâfetu'l-Arabiyye fî̀ Dimaşk”, en-Nibrâs, 1. y11/8 (5 Teşrîn-i Evvel 1909) 300.

Galâyînî, Târîhunâ kable'd-dustûr ve ba 'dehû, Kudüs 1334.

Göçemen, Yakup, "Mısırlı Neo-Klasik Şair Veliyyüddin Yeken'in Şiirlerinde Sultan II. Abdülhamid", Dokuz Eylül Üniversitesi İlahiyat Fakültesi Dergisi, 51, 2020, s. 215-248.

Hamed, Abdullah Hıdır, Kadâyâ 'ş-şi 'ri'l- 'Arabiyyi'l-hadîs, Beyrut: Dâru'l-Kalem, t.y. 
Hâzin, Vilyem, "Melâmih el-kavmiyye fi'ş-şi'ri'l-“Arabiyyi'l-hadîs”, el-Edîb 2 (1978), 15-18.

Da'ûk, Kâmil Muhyiddin, 'Ulemâunâ fỉ Beyrût, Beyrut: 1970.

K1lıç, Hulusi, "Mustafa el-Galâyînî”, Türkiye Diyanet Vakfi İslam Ansiklopedisi, 31/301-302. İSTANBUL: TDV Yayınları. 2006.

Mar'aşlî, Yusuf, , Nesru'l-cevâhir ve'd-durer fì 'ulemâi 'l-karni'r-râbi ' 'aşer, Beyrut: Dâru'l-Ma'rife, 2006.

Muhammed Hüseyn, el-Itticâhâtu'l-vataniyye fi'l-edebi 'l-mu 'âsır, Kahire, Mektebetü'l-Âdâb, 1954.

Neccâr, Âyide, Sahâfetu Filestîn ve'l-haraketu'l-vataniyye fì nısf karn 1900-1948, Beyrut: elMüessestu'l-‘Arabiyye li'd-Dirâsât ve'n-Neşr, 2005.

Özdemir, Y1lmaz, 19. Yüzyılda Lübnan'da Arap Dili Grameri Çalışmaları, Marmara Üniversitesi Sosyal Bilimler Enstitüsü, Doktora Tezi, İstanbul 2005.

Rîmâvî, Süheyle - Ed-Dehâmişe, Bâsim, "eş-Şeyh Mustafa el-Galâyînî: Hayâtuhu ve fikruh 18861945)", Dirâsât: el- 'ulûmu'l-insâniyye ve'l-ictimâ 'iyye 26 (ek) (1999): 830.

Şâfi'î, Mahmud Saîd Teşnîfü'l-esmâ' 'bi-şuyûhi'l-icâze ve's-semâ', Kahire: Dâru'l-Kutubi'l-Misriyye, 2013.

Velî, Tâhâ, Beyrût fi 't-târîh ve'l-hadâra ve'l- 'umrân, Beyrut: Dâru'l-'İlm li'l-Melâyîn, 1993.

Yusuf İzzeddin, eş-Şi 'ru'l- 'İâkiyyu'l-hadîs ve eseru't-teyârâti s-siyâsiyye ve'l-ictimâ' 'iyye fìh, Bağdat: Matba'atu Es'ad, 1960.

Zeki Muhammed Mücâhid, el-A 'lâmu'ş-şarklyye, Beyrut: Dâru'l-Garbi'l-İslâmî, 1994.

Ziriklî, Hayruddin, el-A 'lâm, Beyrut: Dâru'l-'İlm li’l-Melâyîn, 2002. 
